UH

iti

Universität Hamburg
Faculty Economics and Social Sciences Chair for Economic Policy

ASSESSING EXTERNAL EFFECTS OF CITY

AIRPORTS: LAND VALUES IN BERLIN

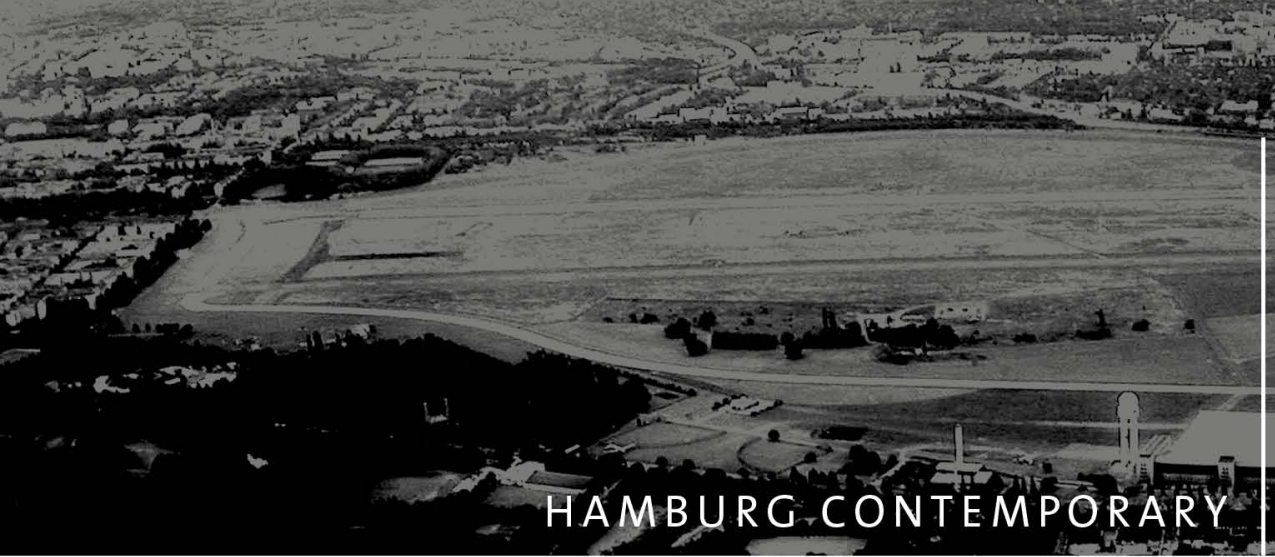

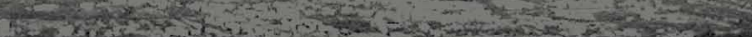

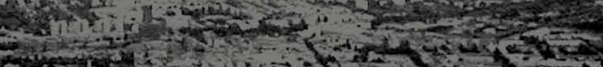

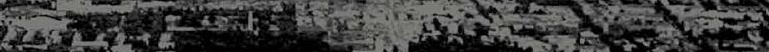

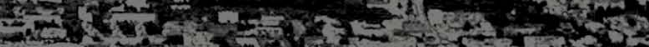

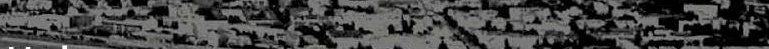

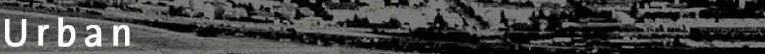
Transport sports SocioRegional
Real Estate
Architectural Regional
Real Estate
Architectural ECONOMIC DISCÚSSTONS

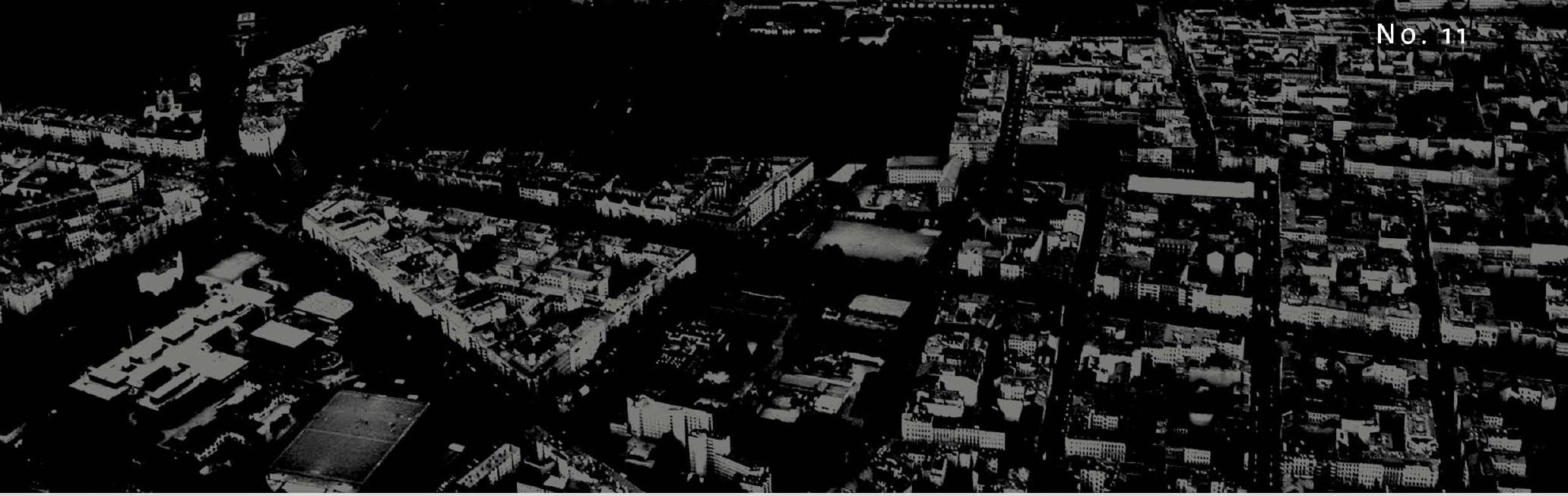


Hamburg Contemporary Economic Discussions

University of Hamburg

Faculty Economics and Social Science

Chair for Economic Policy

Von-Melle-Park 5

D-20146 Hamburg | Germany

Tel $+494042838-4622$

$\mathrm{Fax}+494042838-6251$

http://www.uni-hamburg.de/economicpolicy/

Editor: Wolfgang Maennig

P. Gabriel M. Ahlfeldt

University of Hamburg

Faculty Economics and Social Science

Chair for Economic Policy

Von-Melle-Park 5

D-20146 Hamburg | Germany

Tel $+494042838-5569$

Fax +494042838 - 6251

ahlfeldt@econ.uni-hamburg.de

Wolfgang Maennig

University of Hamburg

Faculty Economics and Social Science

Chair for Economic Policy

Von-Melle-Park 5

D-20146 Hamburg | Germany

Tel $+494042838-4622$

$\mathrm{Fax}+494042838-6251$

maennig@econ.uni-hamburg.de

ISSN 1865 - 2441 (Print)

ISSN 1865 - 7133 (Online)

ISBN $978-3-940369-36$ - 9 (Print)

ISBN 978 - 3 - 940369 - 37 - 6 (Online) 


\title{
Assessing External Effects of City Airports: Land Values in Berlin*
}

\begin{abstract}
This paper employs a hedonic price model to explain standard land values in Berlin. Impact on land values is assessed for the two city airports situated in Berlin, Germany, Tempelhof and Tegel. Empirical results confirm expectations about the impact of various attributes on land values. Areas exposed to noise pollution of downtown airport Tempelhof sell at a discount of approximately $5-9 \%$ within a distance of $5000 \mathrm{~m}$ along the air corridor. No significantly negative impact was found for land values around Tegel Airport, which is located in a central, but less densely populated, area. Market access indicators created for all three Berlin airports in operation, including Berlin Schoenefeld International Airport, reveal clear location advantages in terms of accessibility of Tempelhof and Tegel compared to Schoenefeld Airport, where the new Berlin Brandenburg International Airport is about to be developed.
\end{abstract}

Keywords: Air Traffic, Land Values, Airport, Hedonic Regression, Berlin

JEL classification: $R_{31}, R_{42}, R_{53}$

Version: April 2008

\section{Introduction}

While large cities depend on major airports carrying out hub functions to provide various international non-stop connections, smaller downtown business airports are much appreciated by businessmen due to their accessibility. Neighbourhood activists usually oppose these airports mainly because of extensive noise pollution and emissions. Opposition obviously becomes stronger the more central airports are located, since population density is typically found to be much higher in

\footnotetext{
* We are grateful to Stephen J. Redding, Daniel M. Sturm and Nikolaus Wolf for sharing some valuable data. We acknowledge the support of the Berlin Senate Department for Urban Development in person of Markus Breithaupt and Monika Mischlinsky who kindly provided the GIScontent which allowed for bringing the geographic dimension into this research. We also would like to thank seminar participants at University of Hamburg, in particular Marc Gronwald, for most helpful comments and suggestions.
} 
downtown areas. As a consequence, local authorities are confronted with two conflicting interests, emphasizing the role of downtown airports as a location factor to attract businesses on the one hand and the necessity of protecting local residents' living quality on the other. To make appropriate decisions, politicians have to rely on valid information about the extent to which residents are effectively exposed to the external effects mentioned. As attractiveness of real estate is immediately capitalized into prices, any considerable external impact of airports should be reflected in price differences. External effects being monetarily quantifiable, politicians may take into account wealth effects on local residents and consequently better determine feasible compensation.

Due to the importance of external effects of airports on affected residents, local authorities and real estate analysts, the impact of airports has attracted scholars' attention. BELL (2001) provides a survey on the impact on residents' physical condition and introduces effects on property prices. Most empirical studies available so far focus on North America (MIESZKOWSKI \& SAPER, 1978; NELSON, 1979; UYENO, HAMILTON, \& BIGGS, 1993) or United Kingdom, where Manchester Airport has attracted much attention (COLLINS \& EVANS, 1994; PENNINGTON, TOPHAM, \& WARD, 1990; TOMKINS et al., 1998). Little evidence is available for continental Europe. Surveys on the empirical literature show that airports are clearly found to adversely affect property values (NELSON, 1980; VAN PRAAG \& BAARSMA, 2005).

Besides being only the second analysis of a case in continental Europe, this study adds three new aspects to the existing literature: First, it analyses two airports, Tegel (IATA Code: TLX) and Tempelhof (IATA Code: THF) in one city. It addresses important dissimilarities between the airports: Tegel Airport presently handles ten times as many passengers a year as Tempelhof Airport. And building structure and land use of surrounding properties also differ considerably between the airports. While Tegel's air corridor covers large water space with an industrial area to the west and low-density residential areas to the east, Tempelhof Airport is embedded in a high-density residential area of $19^{\text {th }}$ century five-storey buildings. 
Comparing the effects generated by varying levels of air traffic on distinctly developed areas might provide valuable insights into the nature of the effects of noise on location attractiveness and capitalization into property prices.

Second, both Tegel and Tempelhof Airports are located relatively centrally and are surrounded by developed areas potentially adversely affected, whereas most airports in the studies mentioned above are outside city boundaries.

Third, this paper applies a hedonic model using highly disaggregated data of 15,937 official statistical blocks, the most disaggregated level available at the Statistical Office of Berlin. To analyse this highly disaggregated dataset we employ GIS tools and a projected GIS map of the official block structure including information on public infrastructure, such as schools, playgrounds and railway stations, enabling generation of impact variables.

The remainder of this article is organized as follows. In Section 2 we present Tegel and Tempelhof Airports in more detail while section 3 discusses the data. In Section 4 our empirical strategy is developed and results are presented in Section 5. The final section concludes the paper and provides an outlook for the future.

\section{Berlin Airports Tegel and Tempelhof}

The official inauguration of Tempelhof was in 1923. After complete redevelopment during the national socialist regime, Tempelhof was clearly Germany's most important air hub with a maximum capacity of 6 million passengers a year, exceeding the effective 1934 numbers by a factor of thirty. ${ }^{1}$ These dimensions, the facility design and architectural and historical particularities have frequently been discussed (CARRÉ, 2000; DEMPS \& PAESCHKE, 1998; MEUSER, 2000; SCHMITZ, 1997). Tempelhof later became internationally prominent as Berlin's most impor-

Facility extensions were designed by the architect Enst Sagebiel in 1934. Even by the end of WWII facilities had not been finished completely. 
tant access point for the 1948-49 airlift established to supply West Berlin residents during the Berlin Blockade. To provide the necessary capacity, two more airports were conceptualised, one of which was Tegel Airport, jointly operated by the French since 1948.

By the mid $20^{\text {th }}$ century, Berlin possessed a decent infrastructure for air traffic and was preparing itself to benefit from the rapidly growing market. However, Berlin soon lost its status as Germany's pre-eminent hub, due to loss of market access following Germany's division (REDDING, STURM, \& WOLF, 2007). West Berlin became completely surrounded by the Soviet zone of occupation. While the most important West Germany counterpart of the airlift - Frankfurt - emerged as Germany's new pre-eminent hub, generating more and more traffic and continuously expanding facilities, improvements in air traffic infrastructure in West Berlin remained relatively modest.

As no reserve space for extension of facilities was available in Tempelhof due to its downtown location, Tegel Airport was opened for civilian air traffic in 1960 to meet the demands generated by increasing national and international air traffic, and the fact that a flight connection was the only way of travelling between West Berlin and West Germany avoiding border controls. In 1974, a new civilian terminal in the south of Tegel airfield replaced the existing facilities which subsequently have been used for military and governmental purposes only.

Following the inauguration of the new Tegel Airport, Tempelhof Airport was closed until 1984 when it was reopened mainly for smaller airplanes utilized by business travellers. Despite minor extensions during the following decades, Tegel Airport kept moderate size. Even experiencing a considerable capacity overload (STEINKE, 2006), the number of served passengers at Berlin's Tegel Airport has still not exceeded 12 million per year, a relatively small number compared to 52 million at Fankfurt or even over 67 million at London Heathrow in 2005. Figure 1 shows passenger traffic at Berlin airports since reunification in 1990. 


\section{Fig. 1 Passenger Traffic at Berlin Airports}

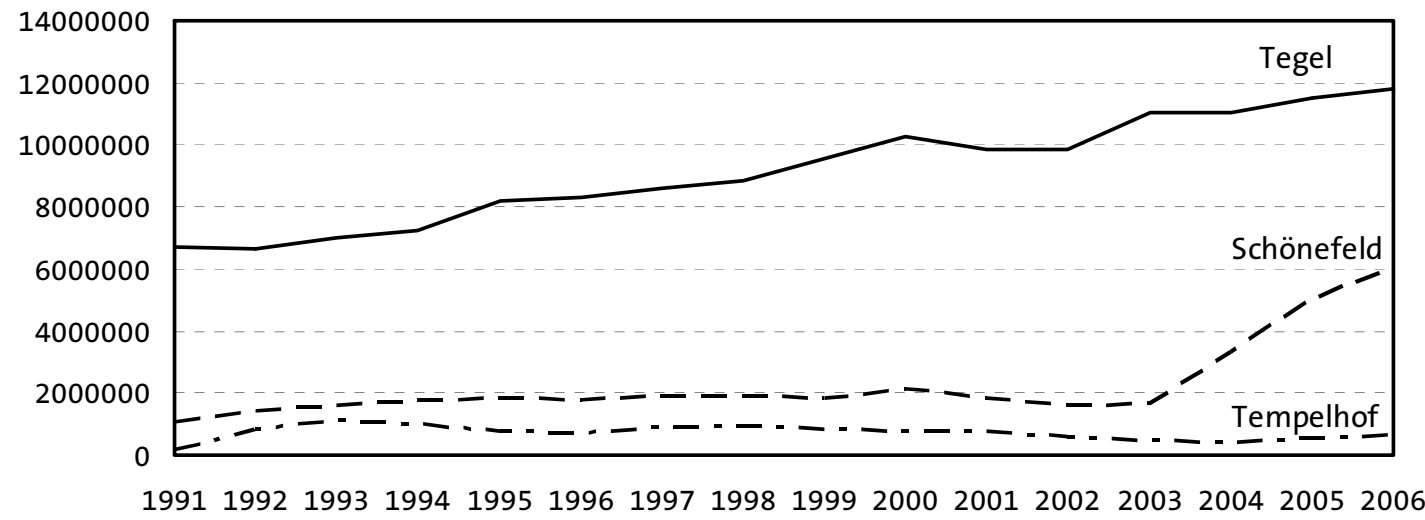

Source: German Airports Association. URL: http://www.adv-net.org/eng/gfx/index.php.

As noted above, the capacity of both airports is restricted by their central location and good accessibility. Figure 2 shows the location of the airports and the officially determined noise protection zones. Small noise protection zones reflect the relatively low air traffic at Tempelhof, which lies within an area of high population density. Compared to the city airports at Tegel and Tempelhof, the location of Schönefeld is remote. In recent years, Schönefeld, which will be redeveloped as the new Berlin Brandenburg International (BBI) Airport, has become much appreciated by low-cost carriers due to low operating costs. However, Tegel continues being the most important airport for business flights and the only airport in Berlin to offer intercontinental connections. Tempelhof, much smaller, is predominantly used by businessmen. Therefore, due to custom and connection to the central business district (CBD) areas, both city airports are particularly appreciated by the business community. 


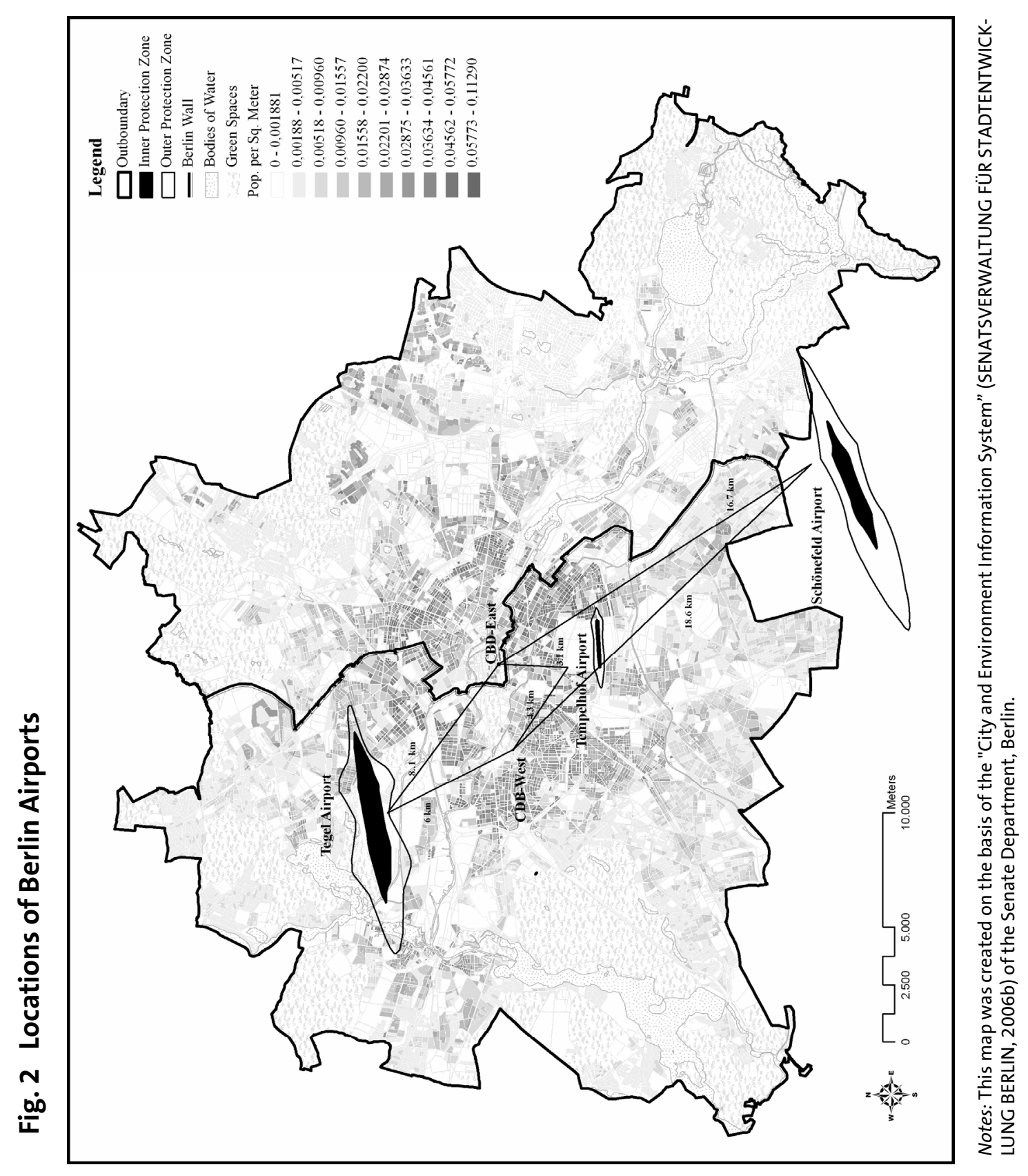


While Tegel Airport will continue in operation until 2011, when the new BBI Airport is inaugurated, Tempelhof's closure has already been scheduled for October 31, 2008. The external effects of Tempelhof Airport are judged differently by citizens: Some neighbourhood activists' movements favour the final shutdown while the Interest Group of City Airport Tempelhof (ICAT) promisingly pleads for a referendum in favour of Tempelhof Airport remaining in operation. Tegel Airport, presently Berlin's largest airport, is foreseen to serve exclusively as a governmental airbase after 2011. Legal claims of airlines opposing Tegel's closure have been rejected by the administrative appeals tribunal responsible.

\section{Data and Data Management}

The study area covers the whole of Berlin, the capital city of Germany, which on July 30, 2006, had 3,399,511 inhabitants in an area of approximately $892 \mathrm{~km}^{2}$. We use standard land values ("Bodenrichtwerte"), assessed by the local Committee of Valuation Experts ("Gutachterausschuss") as our primary endogenous variable. Standard land values are given in values per square meter for zones of similar use and valuation ("Bodenrichtswertszonen"), assessed by statistical evaluation (including elimination of outliers) of all transactions during the reporting period. Assessed values reveal market values for undeveloped properties within the zone of valuation and refer to typical density of a development provided in the form of a typical floor space index (FSI) value for the zone. ${ }^{2}$ The FSI, also called floor space ratio (FSR), is the ratio of building total floor area to the area of the corresponding plot of land. Additionally, each standard land value is assigned to a class of land use, indicating whether the respective area is characterized by major retail and/or business activity, or industrial or residential use.

${ }^{2}$ More information on data sources and the process of collection of standard land values is described in the Appendix. 
The data refers to the 15,937 official statistical block structure, the most disaggregated level available at the Statistical Office of Berlin. The statistical blocks have a median surface area of less than $20,000 \mathrm{~m}^{2}$, approximately the size of a typical inner city block of houses. The mean population of the 12,314 populated blocks was 271 (median 135). ${ }^{3}$ To analyse this highly disaggregated dataset we employed GIS tools and a projected GIS map of the official block structure including information on public infrastructure, such as schools, playgrounds and railway stations, enabling generation of impact variables, which are discussed in more detail in the section below. ${ }^{4}$ Furthermore, we use population data at block level, including demographic characteristics from the Statistical Office of Berlin. All data used in this paper strictly refer to the end of 2005 with the exception of employment in the workplace which were only available at the Senate Department for the end of $2003 .^{5}$

\section{Empirical Strategy and Methodological Issues}

\subsection{Baseline Hedonic Modelling}

We develop a hedonic pricing model to explain the present land value pattern in Berlin. We then extend the basic model by a set of variables capturing the impact of the airports on land values. Hedonic models are commonly applied in real estate and urban economics since they treat real estate commodities as bundles of attributes. Examples of hedonic pricing models in urban economic literature include construction of house indices (CAN \& MEGBOLUGBE, 1997; MILLS \& SIMENAUER, 1996; MUNNEKE \& SLADE, 2001), impact assessment of quality of

\footnotetext{
${ }^{3}$ There are much larger blocks, especially in the outer areas of Berlin. These typically cover recreational areas such as parks, forests and lakes, which are undeveloped and unpopulated and, therefore, omitted in the present study.

${ }^{4}$ All GIS maps were provided by the Senate Department of Urban Development (Senatsverwaltung für Stadtentwicklung) and are based on the "City and Environment Information System" (SENATSVERWALTUNG FÜR STADTENTWICKLUNG BERLIN, 2006b) of the Senate Department.

Standard land values of 2006 are assessed on the basis of transactions from the reporting period year of 2005.
} 
public services (BOWES \& IHLANFELDT, 2001; GATZLAFF \& SMITH, 1993), school quality (MITCHELL, 2000), group homes (COLWELL, DEHRING, \& LASH, 2000), churches (CAROLL, CLAURETIE, \& JENSEN, 1996), supportive housing (GALSTER, TATIAN, \& PETTIT, 2004) and sports stadiums (AHLFELDT \& MAENNIG, 2007; TU, 2005). Impact of aircraft noise has frequently been assessed using hedonic models (COLLINS \& EVANS, 1994; MIESZKOWSKI \& SAPER, 1978; NELSON, 1979; PENNINGTON, TOPHAM, \& WARD, 1990; TOMKINS et al., 1998; UYENO, HAMILTON, \& BIGGS, 1993; VAN PRAAG \& BAARSMA, 2005).

Following GALSTER, TATIAN \& PETIT (2004), we assume that the characteristics of real estate can be described by their structural attributes [S], and a set of attributes capturing the effects of the neighbourhood $[N]$ and local public services $[L]$ (MUELLBAUER, 1974; ROSEN, 1974) as in the following equation:

$$
H=f([S],[N],[L])
$$

$H$ is the aggregated value of attribute characteristics, which translates into a market value or sales price $(P)$ following a determined functional relationship:

$$
P=g(H)
$$

In urban and real estate economic literature, it is common to assume this relationship is log-linear, allowing for a non-linear relationship between price and attribute values and being more intuitively interpretable than other non-linear models. When interpreting regression results, the attribute coefficient gives the percentage impact of changes in attribute value on property value. For coefficient values smaller than $10 \%$, this rule may also be applied to dummy variables (ELLEN et al., 2001). ${ }^{6}$ Following TU (2005), the relationships in (1) and (2) can be formulated more precisely in the regression equation

\footnotetext{
${ }^{6}$ For larger coefficient values, a simple formula is strongly recommended, providing a much better approximation. For parameter estimate $b$, the percentage effect is equal to $\left(e^{b}-1\right)$ (HALVORSEN \& PALMOUUIST, 1980)
} 


$$
\ln (P)=\alpha+\beta_{1} S_{1}+\ldots+\beta_{i} S_{i}+\gamma_{1} N_{1}+\ldots+\gamma_{j} N_{j}+\delta_{1} L_{1}+\ldots+\delta_{k} L_{k}+\varepsilon
$$

where $i, j$ and $k$ represent the number of attributes, $\beta, \gamma$ and $\delta$ represent the coefficients and $\varepsilon$ is an error term.

In recent publications much attention has been paid to the characteristics of real estate units (ELLEN et al., 2001; GALSTER, TATIAN, \& PETTIT, 2004; HEIKKILA et al., 1989; TU, 2005). To compare property transactions it is necessary to correct all transactions for a complete set of unit characteristics. Indeed, a feasible correction for unit characteristics enables reference to land values instead of property prices (HEIKKILA et al., 1989). As we directly focus on land values as the endogenous variable, we can largely move away from unit characteristics and even the price-lot size relationship. ${ }^{7}$ We focus on other factors and develop a model which describes Berlin's land value pattern through a comprehensive set of explanatory variables covering land use, accessibility indicators, natural endowments, public services provision and variables representing density and composition of neighbourhood populations.

We capture land use by dummy variables that identify blocks where considerable retail or business activity takes place or where the main use is industrial, ${ }^{8}$ the remaining blocks representing residential areas. We use a variable representing the typical block FSI value, allowing for a quadratic term, since land value is expected to increase at a declining rate with increasing FSI.

Location characteristics are captured by a set of distance variables reflecting accessibility and proximity to amenities. Following VON THÜNEN (1826) and ALONSO (1964), the most important accessibility indicator is the distance to CBD

\footnotetext{
${ }^{7}$ Lot size was typically found to have a concave functional impact on land values (COLWELL \& MUNNEKE, 1997; COLWELL \& SIRMANS, 1993). Later, a convex structure was indicated within the metropolitan area CBDs (COLWELL \& MUNNEKE, 1999).

8 The Committee of Valuation Experts provides information on land use for all land values. A detailed description of data sources is provided in the Appendix.
} 
(CHESHIRE \& SHEPPARD, 1995; DUBIN \& SUNG, 1990; HEIKKILA et al., 1989; ISAKSON, 1997; JORDAAN, DROST, \& MAKGATA, 2004).

In contrast to the usual assumption of one single CBD, Berlin is characterised by duocentricity. This characteristic emerged during the 1920s and was strengthened during the period of division, 1949-1990 (ELKINS \& HOFMEISTER, 1988). Modelling Berlin as a typical monocentric city could lead to biased estimates (DUBIN \& SUNG, 1990). To deal with Berlin's duocentric structure we rely on the official definition of Berlin's Senate Department for Urban Development (SENATSVERWALTUNG FÜR WIRTSCHAFT ARBEIT UND FRAUEN, 2004). As a consequence, our main accessibility measure consists of distance to either CBD West or CBD East. ${ }^{9}$ Figure 2 illustrates the straight line distances from Tegel, Tempelhof and Schönefeld Airports to CBD West and CBD East.

This is a valuable contribution to the land-gradient discussion since there is little empirical evidence available in European and in particular German cities. ${ }^{10}$ Allowing land gradient to vary across land use further enriches our contribution. Of course, distance to CBD is only an approximation; the degree to which the local transportation infrastructure is developed may impact on accessibility. Impact of public transport on property prices has been investigated by GATZLAFF \& SMITH (1993) and BOWES \& IHLANFELDT (2001), who also discussed related sources of negative externalities. We capture the impact of the public transportation network on price pattern using distances to metro and suburban railway stations. To capture externalities created by railroad noise, which have a negative impact on property values (CHESHIRE \& SHEPPARD, 1995; DEBREZION, PELS, \& RIETVELD, 2006), we add distances to overground railways. In the same way, we consider the effects of proximity to bodies of water (lakes and rivers), natural amenities that are expected to be a major determinant for the emergence of high quality

9 We define CBD West as as having Breitscheidplatz as its centre. The centre of CBD East is defined as the crossroads between Friedrichstrasse and Leipzigerstrasse.

${ }^{10}$ Within the last three decades, the few exceptions are evidence from LEE (1993) for Duisburg and from MAENNIG \& PFLEIDERER (2002) for Hamburg. 
residential areas. We also include proximity to playgrounds and schools, providing information on the supply of public services.

As indicators of neighbourhood quality, we add population density and proportion of foreign residents (DUBIN \& SUNG, 1990; TU, 2005). We also consider proportion of other potential low-income groups, such as people over the age of 65, and young professionals and students between the ages of 18 and 27. To assess any impact related to households with children, we use proxy variables of the proportion of the population in the following age classes: below 6; from 6 to 15; and from 15 to 18 .

Recently, there have been attempts to control for location using large sets of dummy variables representing location fixed effects (ELLEN et al., 2001; GALSTER, TATIAN, \& PETTIT, 2004; GALSTER, TATIAN, \& SMITH, 1999; TU, 2005). We use this concept to account for potential East-West heterogeneity by introducing a dummy variable for West Berlin, which we allow to interact with all explanatory variables to allow for heterogeneity of all implicit attribute prices.

Spatial dependence may lead to autocorrelation, leading to inefficient ordinary least squares (OLS) estimates and biased test scores. Intuitively, spatial dependence can be assumed to be the result of external effects of surrounding areas. One explanation for spatial dependence in property prices and rents is that the buyer and seller consider previous transactions that have occurred in the immediate vicinity. To deal with spatial dependence, CAN \& MEGBOLUGBE (1997) used a spatial autoregressive explanatory variable representing a distance-weighted average of local sales prices occurring prior to the transaction. ${ }^{11}$ To determine the value of the spatially lagged variable for block $i$, we weight the land value of neighbouring block $j\left(P_{j}\right)$ with spatial weight

$$
w_{i j}=\left(1 / d_{i j}\right) / \sum_{j}\left(1 / d_{i j}\right)
$$

${ }^{11}$ Since assessed standard land values all refer to the same point in time, we do not define pretransaction period. 
where $\left(1 / d_{i j}\right)$ represents the inverse distance between the centroids of blocks $i$ and $j$. The spatial lag value for block $i$ takes the form

$$
\text { Spatial_Lagi }=\sum_{j}\left[\left(1 / d_{i j}\right) / \sum_{j}\left(1 / d_{i j}\right)\right] P_{j}
$$

Having decided to use a spatial weight matrix, weighted by inverse distance, the spatial extent surrounding properties then needs to be defined. CAN \& MEGBOLUGBE (1997) found a radius of $3000 \mathrm{~m}$ to be superior, taking into consideration only the three nearest properties. TU (2005) used a very similar distance of 1.8 miles. GALSTER, TATIAN \& PETIT (2004) only tested the effectiveness of distinctrange specifications for a small subset of their transaction data. Goodness of fit $\left(R^{2}\right)$ showed minimal impact and so they excluded the spatial lag term. To test which of the specifications proposed by CAN \& MEGBOLUGBE (1997) best matched our requirements, we calculated the inverse distance matrices according to both specifications. Figure 2 shows Moran scatter plots for logarithms of land values for 2006. The plot based on a distance matrix capturing the three nearest blocks (Figure 2 b) clearly exhibits a more linear relationship, better capturing spatial dependence. This is confirmed by a larger Moran's I coefficient. ${ }^{12}$

${ }^{12}$ Comparing the effects of different spatial weight matrices on nominal values yields similar results. We provide scatter plots of logarithms since we use log values as endogenous variables. 
Fig. 2a Spatial Dependence with 3,000 Meter Specification

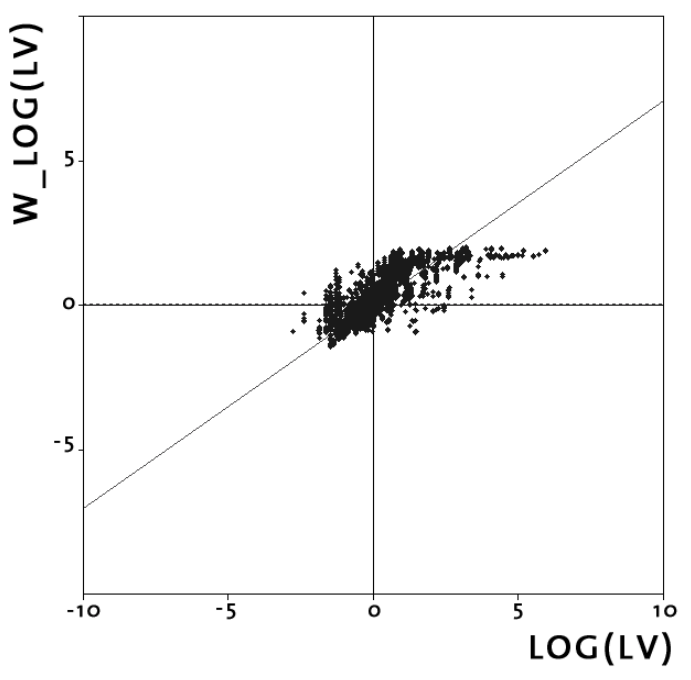

Fig. 2b Spatial Dependence with "3 Nearest Block" Specification

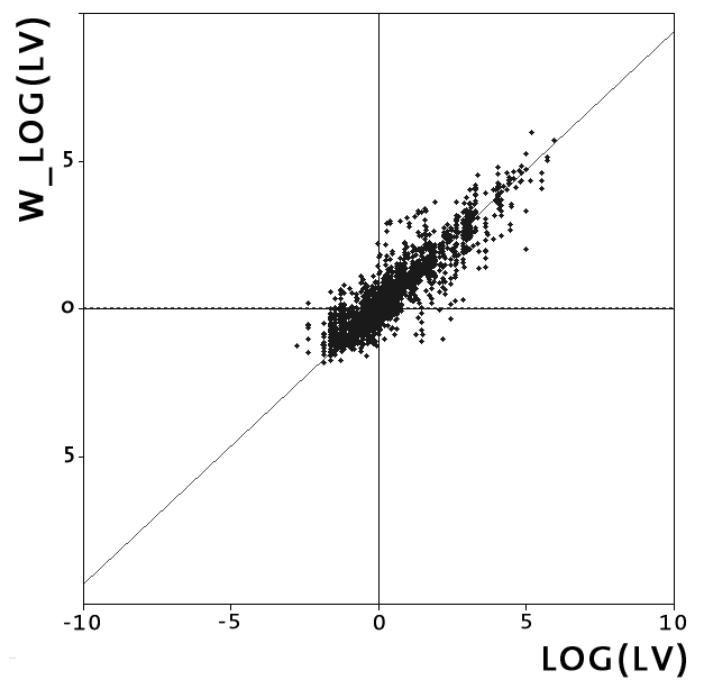

Notes: LOG(LV2006) is a natural logarithm of the standard land values of Berlin for 2006. W_LOG(LV2006) is the corresponding spatial lag value calculated on the basis of the spatial weight matrix. The corresponding Moran's I coefficient is 0.7051 in Figure $2 \mathrm{a}$ and 0.9346 in Figure $2 \mathrm{~b}$.

Spatially lagged variables have positive effects on the explanatory power of models. This is the result of omitting attributes that are most likely to be correlated across space. Due to the large explanatory power of the spatial lag variable (i.e., Moran's I coefficient close to one), we emphasise that the explanatory power of our model depends only to a minor extent on the introduction of the lag term. In Table A2, we compare the performance of our final hedonic baseline regression (1) with performance when omitting the lag term (3). An $R^{2}$ of close to 0.9 indicates that our model performs well when neglecting spatial dependence. ${ }^{13}$ However, the improvements in residuals following the spatial model extension are substantial. In Figure 3, the residuals corresponding to Table A1, Column (3), are plotted in a three-dimensional space. ${ }^{14}$

\footnotetext{
${ }^{13}$ To check for robustness, we consider numerous lag-term specifications, including the two, four, five and six nearest blocks as well as a specification considering all blocks within $1500 \mathrm{~m}$. However, Moran scatter plots and $\mathrm{R}^{2}$ both suggest that the final model is the best fit for capturing spatial dependence.

${ }^{14}$ These residual surfaces also serve as a useful tool to eliminate extreme values. The most western block, isolated and contiguous to Berlin's boundaries within a forest, has an extremely large residual. This indicates that our model, largely calibrated to inner-city areas, does not explain the valuation of an isolated area. Consequently, we omit this observation.
} 
Figure 3 Gridded Residual Surface of Spatially-Extended Model

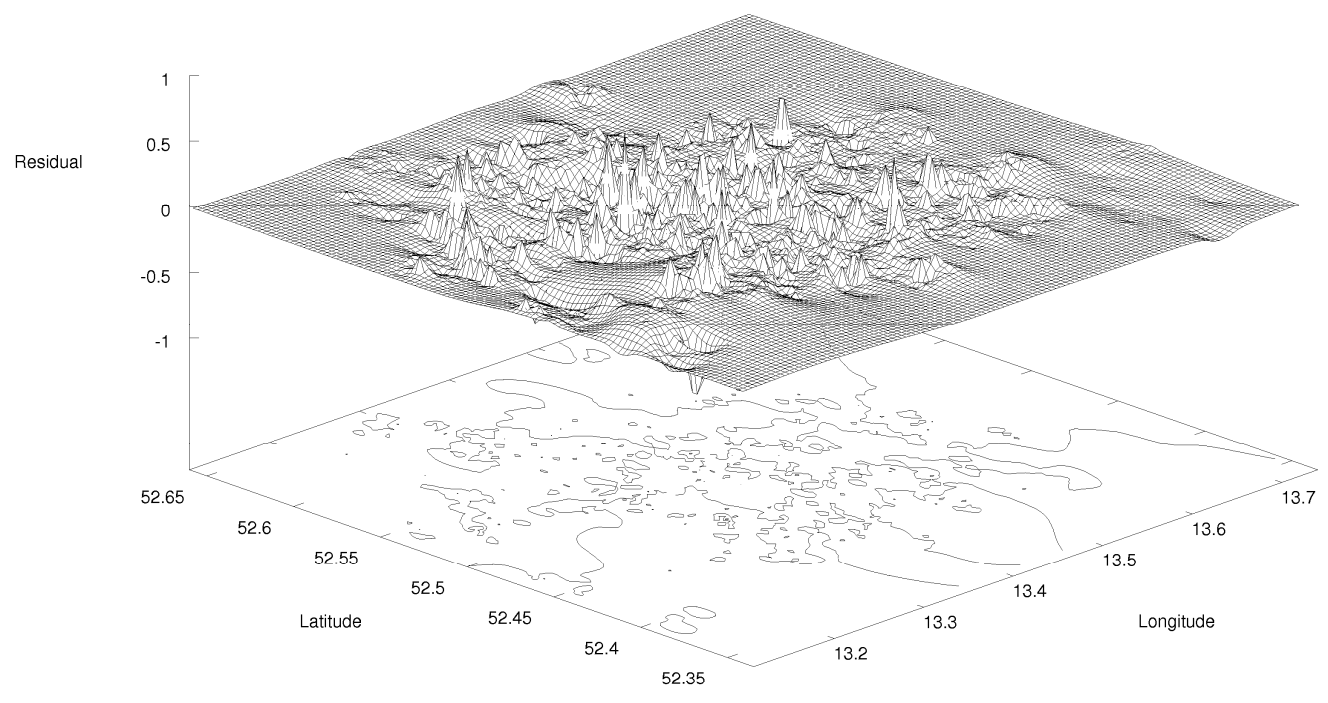

The full model specification can be expressed in the following way:

$$
\begin{aligned}
\operatorname{In}(P) & =\alpha+\beta_{1} \text { Business }+\beta_{2} \text { Industry }+\beta_{3} \text { West } \\
& + \text { STRUCT } a_{1}+\text { LOC } a_{2}+\text { NEIGH } a_{3} \\
& +(\text { Business } \times \text { STRUCT }) b_{1}+(\text { Business } \times \text { LOC }) b_{2} \\
& +(\text { Business } \times \text { NEIGH }) b_{3} \\
& +(\text { Industry } \times \text { STRUCT }) c_{1}+(\text { Industry } \times \text { LOC }) c_{2} \\
& +(\text { Industry } \times N E I G H) c_{3} \\
& +(\text { West } \times \text { SRUCT }) d_{1}+(\text { West } \times \text { LOC }) d_{2}+(\text { West } \times N E I G H) d_{3} \\
& +\gamma \text { Spatial _Lag }+\varepsilon
\end{aligned}
$$

where $\ln (P)$ is the natural logarithm of standard land values; Business, Industry and West are dummy variables capturing land use and spatial heterogeneity; STRUCT, LOC and NEIGH are vectors of structural, locational and neighbourhood characteristics, respectively; and Spatial_Lag is the spatial autoregressive term from (4). $\alpha, \beta, \gamma$ and lower case letters represent the set of coefficients to be estimated and $\varepsilon$ is an error term. In Table A1, in the Appendix, there is a detailed description of the components. Attribute variables interact with dummy variables to allow implicit values to vary across space and land use. 


\subsection{Modelling the Impact of Airports}

We capture irregularities in land value pattern due to the airports by extending our baseline model with variables that attribute unexplained variation to zones of potential impact. Typically, externalities assessed in the urban economic literature can be assumed to spread evenly in all directions. Impact thus can be assessed using simple geometric forms like concentric rings and straight line distances to the potential sources of externalities (ELLEN et al., 2001; GALSTER, TATIAN, \& PETTIT, 2004; TU, 2005).

Assessing impact of noise generated by taking off and landing involves more complex forms, since sources of externalities move at high speed, thereby emanating noise over different locations at different altitudes. To account for the resulting sound pattern, we rely on officially determined protection zones which define areas being similarly affected by aircraft noise. ${ }^{15}$ For each airfield there are two protection zones defined where the inner zone hardly exceeds the airport's territory. However, even outer zones describe areas still being exposed to aircraft noise. Since sonic sound does not halt at the borderline of a determined protection zone, we create larger zones capturing disturbance effects at larger distances. Borderlines of new zones are determined by proportional extension of officially-defined outer zones keeping zones centred on their geographic centroids. The resulting pattern can be interpreted as one of iso-noise lines representing areas similarly affected by noise disturbances. Figures 4 and 5 show the resulting pattern of officially-determined areas of noise protection (zone 1 ) and zones created by augmentation (zones 2-4) for Tempelhof and Tegel Airports. Zones 2-4 have each been enlarged stepwise by $4000 \mathrm{~m}$ on the horizontal diameter. Blocks are assigned to zones according to the location of geographic centroids.

${ }^{15}$ Zones are determined on the basis of data on air traffic and define areas which are exposed to an equivalent continuous sound pressure level of more than $67 \mathrm{~dB}(\mathrm{~A})$. Details are published in the Aircraft noise annual report available at the website of Berlin airports. URL: http://www.berlin-airport.de/EN/UeberUns/Umwelt/FlJahresbericht/Uebersicht.html. 
Fig. 4 Tempelhof Noise Zones

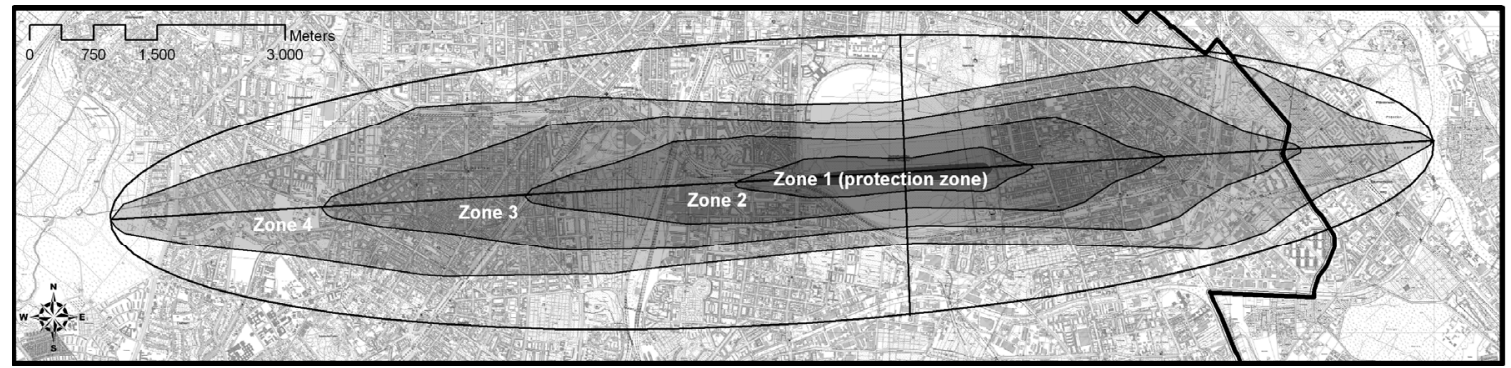

Notes: This map was created on the basis of the "City and Environment Information System" (SENATSVERWALTUNG FÜR STADTENTWICKLUNG BERLIN, 2006b) of the Senate Department, Berlin.

\section{Fig. 5 Tegel Noise Zones}

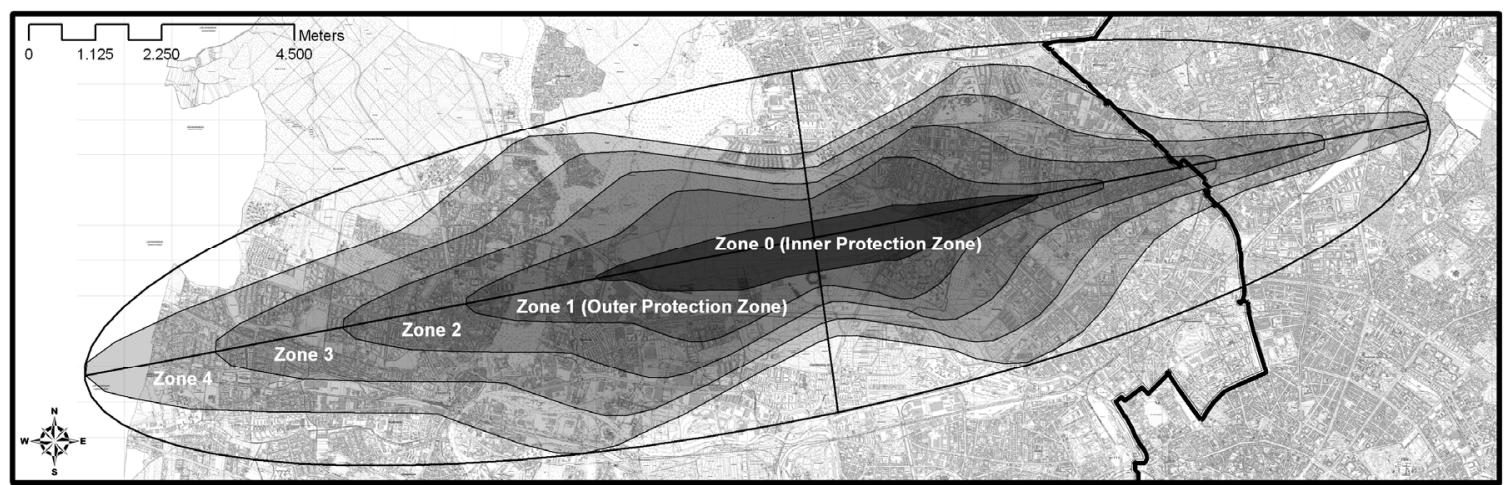

Notes: This map was created on the basis of the "City and Environment Information System" (SENATSVERWALTUNG FÜR STADTENTWICKLUNG BERLIN, 2006b) of the Senate Department, Berlin.

An alternative approach to attribute impact on land values to a potential source of external effects is to introduce distance of property to the location investigation. While this approach is straightforward when externalities can be assumed to spread concentrically, the application of straight line distances to airfield centres would necessarily lead to biased estimates. For instance, a distance of one kilometre to the runway along the air corridor might still be recognized as being close in terms of noise disturbance, while residents living at the same distance on the vertical centre line are likely to feel less perturbed by aircraft approaching and taking off. To deal with this particularity, we calculate equivalent distances in terms of noise perception, relying on simple geometry. We approximate the officially-defined outer protection zone by introducing a symmetric ellipse as exemplified for Tempelhof in Figure 6. 
Fig. 6 Fitted Ellipse for Tempelhof Protection Zone

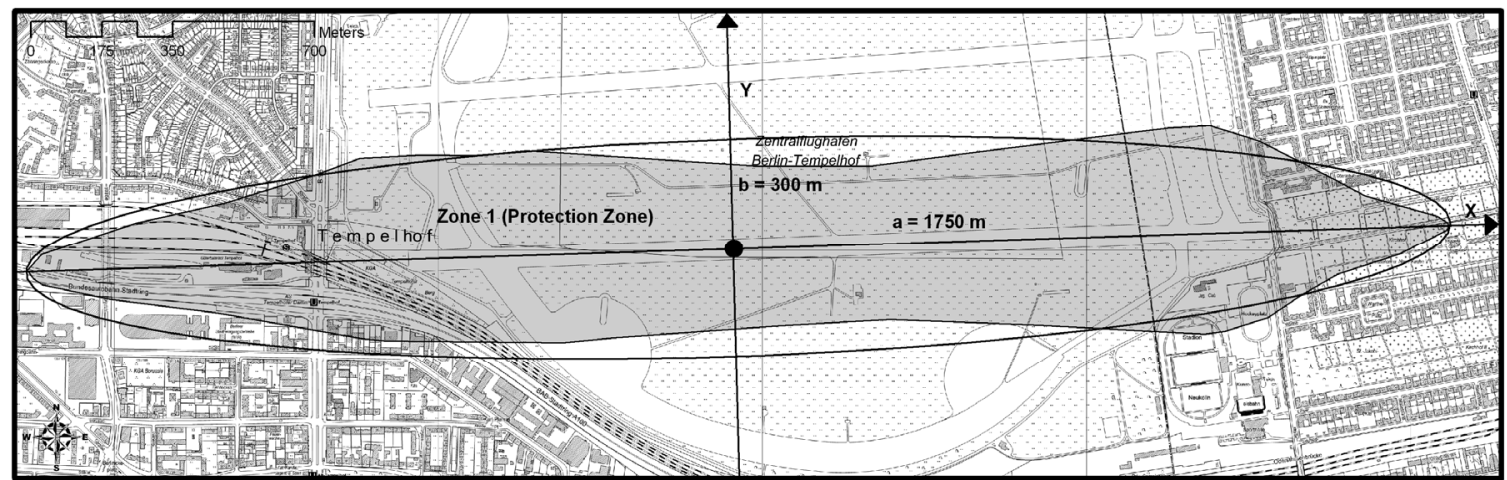

Notes: This map was created on the basis of the "City and Environment Information System" (SENATSVERWALTUNG FÜR STADTENTWICKLUNG BERLIN, 2006b) of the Senate Department, Berlin.

Fitting a coordinate system into the major and minor axes for airfield $j$, the ellipse is perfectly described by semimajor axis $a_{j}$ and semiminor axis $b_{j}$, since the ellipse is the locus of point $i$ fulfilling the condition

$$
\frac{x_{i j}^{2}}{a_{j}^{2}}+\frac{y_{i j}^{2}}{b_{j}^{2}}=1,
$$

where $x_{i j}$ and $y_{i j}$ represent the coordinates of point $i$ relative to the origin of coordinate system $j .{ }^{16}$ Holding $a_{j}$ and $b_{j}$ constant, for every point $i$ in coordinate system $j$, we obtain the value

$$
c_{i j}{ }^{2}=\frac{x_{i j}{ }^{2}}{a_{j}{ }^{2}}+\frac{y_{i j}{ }^{2}}{b_{j}{ }^{2}}
$$

characterising the ellipse in terms of length of semiaxis relative to the original ellipse. Figure 7 compares the ellipse approximating the Tempelhof protection zone to corresponding ellipses for varying values of $c$. Larger values of $c$ imply proportionally increasing semiaxes.

${ }^{16}$ For Tempelhof, $a$ and $b$ take the values of $1750 \mathrm{~m}$ and $500 \mathrm{~m}$, respectively. The corresponding values for Tegel are $5000 \mathrm{~m}$ and $1000 \mathrm{~m}$, respectively. 
Fig. 7 Fitted Ellipse and Equivalent Distances

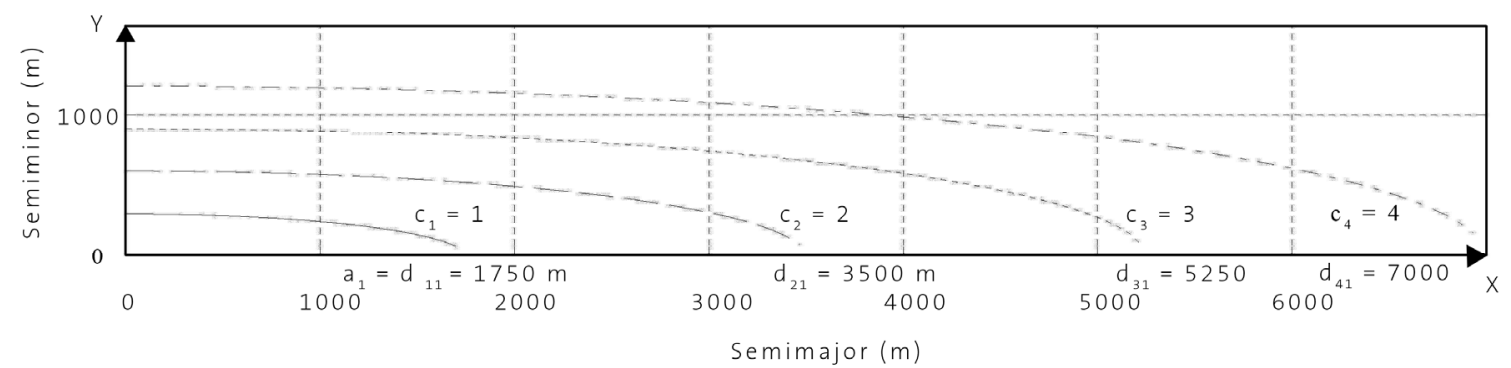

For each point $i$ within the coordinate system, the length of the semimajor axis for the corresponding ellipse can be determined by multiplying the $c$ value by semimajor axis parameter $a_{j}$ of the original ellipse. Thus,

$$
d_{i j}=a_{j} \times c_{i j}=\sqrt{x_{i j}{ }^{2}+\frac{a_{j}^{2}}{b_{j}^{2}} y_{i j}{ }^{2}}
$$

can be interpreted as point $i$ equivalent distance to the centre of airfield $j$ if it lies on the coordinate system's main axis corresponding to the air corridor. $d_{i j}$ provides a comparable distance measure to the source of noise pollution.

\section{Empirical Results}

\subsection{Baseline Hedonic Model}

The baseline hedonic model (Table A2, Column (1)) fits satisfactorily with all coefficients showing the expected signs. The theoretically predicted negative distance-price relationship is much larger for West Berlin. The significantly negative coefficient for West $x$ Dist_Cent can be interpreted as persistence of different spatial equilibriums emerged during the period of Germany's division. In East Berlin, no free markets being allowed, the usual theoretical prediction based on bid-rent theory (ALONSO, 1964) is not applicable. Land gradient varies across space and land use.

Composition and density of population affects land values more or less uniformly in both parts of the city. Population density has a negative impact on area valua- 
tion and the effect is significantly stronger within West Berlin. The coefficient for proportion of foreigners is also significantly negative, indicating that the foreign population indeed concentrates in areas of lower valuation, most probably due to lower incomes. This impact is similar in both parts of the city. The 18- to 27-yearolds also concentrate in areas of relatively lower valuation, probably since this group largely consists of trainees and students who have left home, thus being confronted with budget constraints. In contrast, people over 65 show no major concentration in economically deprived neighborhoods. The coefficient for the proportion of population below the age of six, a proxy for families with young children, is significantly positive.

Centrality is important, although the significantly positive coefficient for Business $x$ Dist_Cent shows that the location premium that business users are willing to pay is not linked strongly to distance from CBD.

\subsection{Empirical Impact of Berlin Airports on Land values}

Figures 4 and 5 show four mutually exclusive zones for Tempelhof and Tegel Airports defined on the basis of official protection zones. Ellipses fitted around the boundaries of the outer zones define the general neighbourhoods. Fixed effect for these zones is captured by introduction of dummy variables denoting blocks whose centroids lie within these areas. Blocks lying within zones 1-4 are similarly represented by dummy variables capturing noise effects across space. The results of this basic impact model are presented in Column (1) of Table 2 for Tempelhof and Column (2) for Tegel. 
Tab. 1 Empirical Results of Baseline Impact-Models

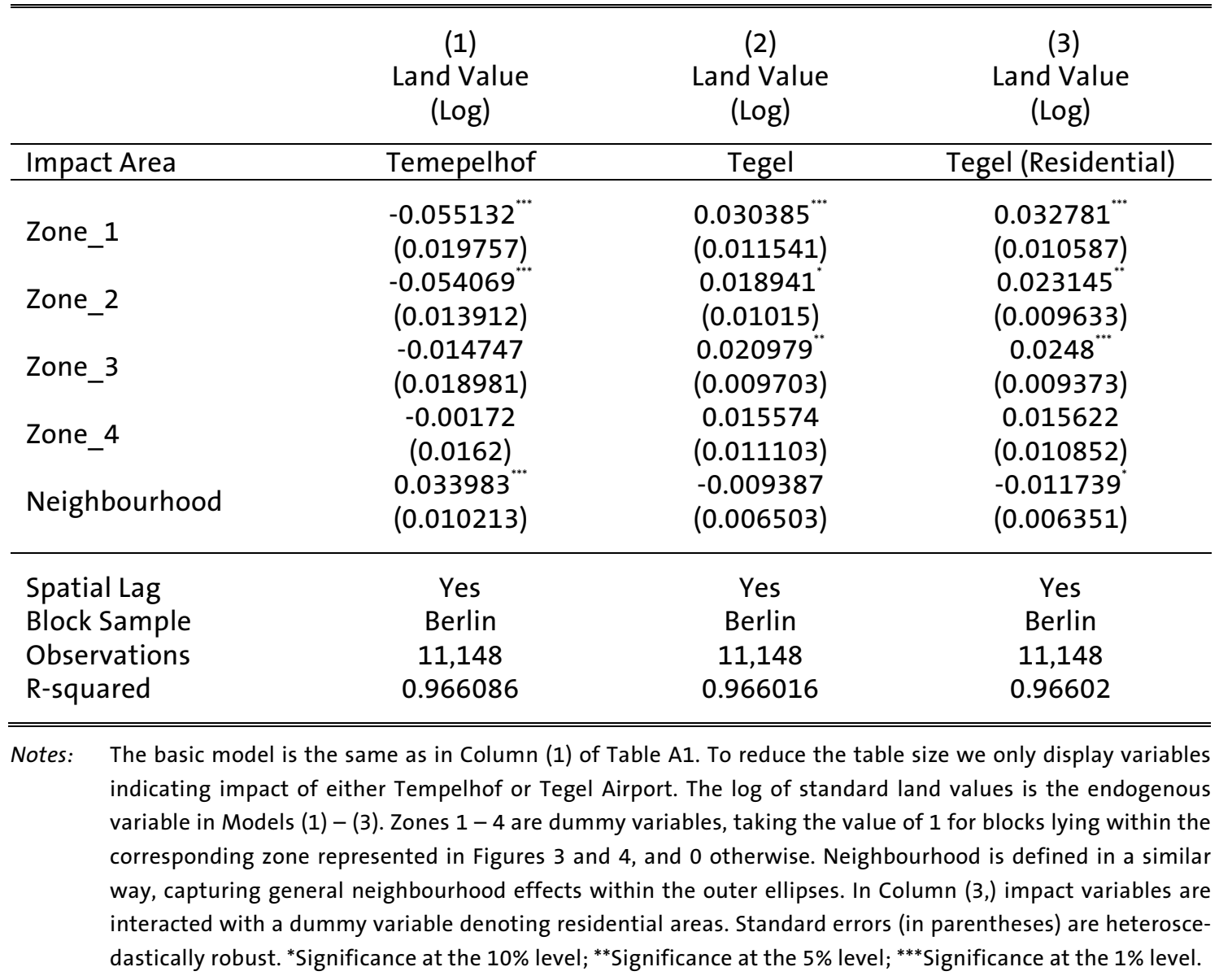

Neighbourhood effects for Tempehof Airport are positive, indicating that properties sell at a location premium. Coefficient estimates for outer zones 3 and 4 are not significant at conventional levels reflecting that there are no additional location characteristics capitalized into prices. In contrast, coefficients for the two inner zones 1 and 2 have negative values of similar size and are statistically significant. These suggest a negative impact of $5.5 \%$ within an area of approximately $7.5 \mathrm{~km}$ in length and $1 \mathrm{~km}$ in width. ${ }^{17}$

Results for Tegel Airport are different and more surprising. While coefficients for the general neighbourhood and zone 4 are not statistically significant, results suggest a location premium of $2 \%$ for properties within zones 2 and 3 , and up to

\footnotetext{
${ }^{17}$ The area extends slightly more to the west $(4 \mathrm{~km})$ than to the east $(3.5 \mathrm{~km})$.
} 
$3 \%$ for zone 1 . The Tegel air corridor, particularly the western wing, covers a large industrial area nerved by bodies of water. As land values within these areas may feasibly be assumed to react relatively inelastically to noise pollution, we repeat the estimation for Tegel Airport considering only impact on blocks exclusively used for residential purposes (Column (3)). However, the coefficients reveal the same picture.

Results so far suggest a significantly negative impact of airports on land values within zones 1 and 2 of Tempelhof Airport. To assess whether within these zones there is a clear relationship between impact and distance, we introduce equivalent distances as described in the methodological section. In Table 2 we capture the impact of Tempelhof by introducing a dummy variable denoting all blocks lying within zones 1 and 2 where impact was previously found to be significant. Also interacting this dummy variable with the equivalent distance variable (Column (1)) reveals a significantly positive distance-impact relationship.

Results suggest that along the air corridor impact diminishes from approximately 9\% to $5 \%$ after $5 \mathrm{~km}$, a distance corresponding to zone 2 of Tempelhof Airport. The same approach applied to Tegel Airport (Column (2)) reveals no distanceimpact relationship significantly different from zero. Within zone 1 , positive impact even increases with proximity (Column (3)), although the coefficient estimate is extremely close to zero. Results of Columns (1) and (3) are illustrated in Figure $8 .^{18}$

${ }^{18}$ In terms of equivalent distances, zone 1 of Tegel $(5500 \mathrm{~m})$ compares to zone 2 of Tempelhof $(4500 \mathrm{~m})$. We consequently choose to present impact based on the results of Table 3, Columns (1) and (2), for an equivalent distance range of $0-5000 \mathrm{~m}$. 
Tab. 2 Empirical Results of Estimates Based on Equivalent Distances

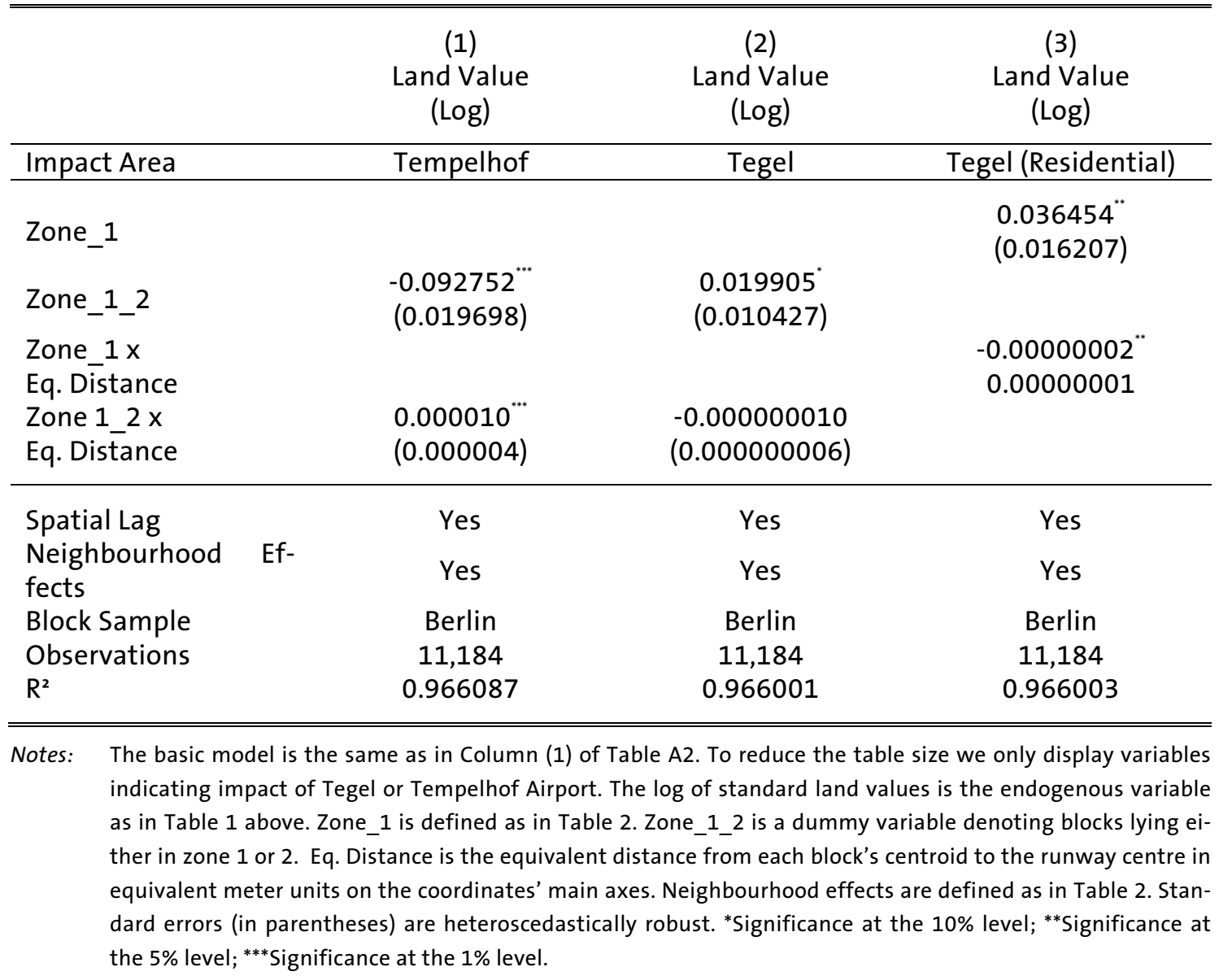

Fig. 8 Impact Tempelhof and Tegel Airports

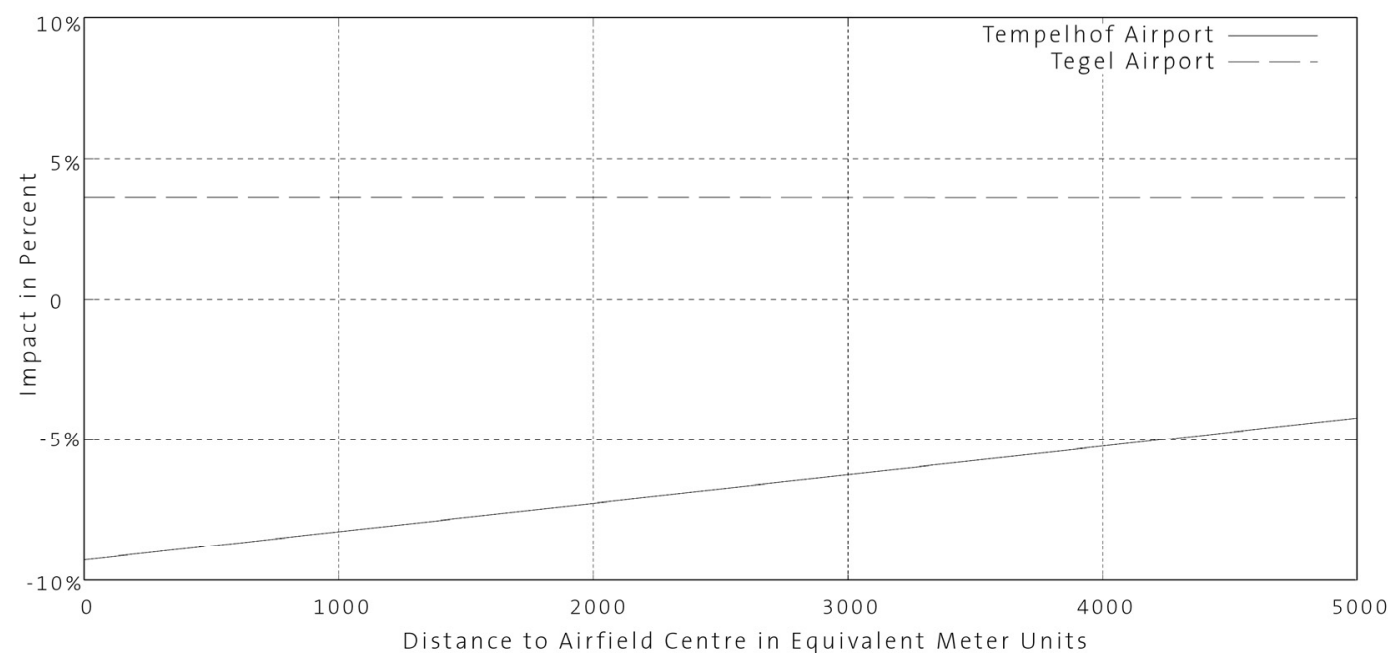

Notes: Graphs displayed in this figure illustrate the coefficient estimates represented in Table 3, Columns (1) and (3). 
Both approaches based on mutually exclusive zone dummy variables and equivalent distances basically yield the same results. These results are particularly surprising in the light of much larger aircraft taking off and landing at Tegel Airport and at much greater frequency compared to Tempelhof Airport. However, as noted above, building structure within the air corridors of Tempelhof and Tegel Airports differ substantially. This is reflected by an average population density of more than twice within zones 1 and 2 of Tempelhof Airport ( 0.025 inhabitants per square meter) compared to the corresponding zones of Tegel Airport (0.009). ${ }^{19}$

Our results suggest that owners of detached family houses in the vicinity of Tegel Airport react less sensitively to noise distortions than renters living in downtown apartments around Tempelhof Airport. These results are in line with previous findings indicating that prices of multistorey condominiums react more strongly to noise distortion generated by air traffic than those of detached houses (UYENO, HAMILTON, \& BIGGS, 1993).

In the case of Berlin, this may partially be attributable to higher mobility of residents living in proximity to Tempelhof Airport. First, owners of detached family houses may be less free in choice of potential residence and less willing to move out of their homes. Secondly, as shown, residents living within the two inner zones of Tegel are older on average than those living within the corresponding zones of Tempelhof and may, therefore, be assumed to be less mobile. ${ }^{20}$ Another explanation might be extra public payment for installation of passive noise protection leading to neutralization of distortions. Owners of detached family houses being immediately affected by aircraft noise in the vicinity of Tegel are more likely to install noise protection than landlords renting out apartments situated within the Tempelhof air corridor.

19 Median block population density differs even more substantially (0.0217 to 0.004).

${ }^{20}$ Comparing mean proportions of age groups within zones 1 and 2 of Tegel and Tempelhof Airports reveals that proportions are larger for all age groups below the age of 45 for Tempelhof while above 45 for Tegel. 
Figure 1 shows the locations of Tegel and Tempelhof Airports and provides distances to CBDs as a simple accessibility indicator. We make use of highly disaggregated population and employment (at workplace) data to calculate more precise accessibility indicators for all three Berlin Airports. Following the tradition in economic geography, we represent airport accessibility $j$ for residents by population potentiality $P P_{j}$, which is the distance-weighted sum of population of all instances of block $k$ in Berlin $\left(P_{k}\right)$.

$$
P P_{i j}=\sum_{k} P_{k} \times \exp \left(-\alpha \times r_{j k}\right)
$$

where $\alpha$ is the distance decay factor and $r_{j k}$ is the shortest road distance between block $k$ and airport main entrance $j$. $\alpha$ takes the value of 0.5 , a typically applied value in the urban economic and economic geography literature (WU, 2000). Employment potential is calculated analogically using data on employment at workplace to reflect accessibility from businessmen's perspective. In terms of accessibility, Tempelhof Airport is clearly the most favourable from both a resident's (population potentiality) and a businessman's (employment potentiality) point of view. Just considering Berlin residents and employees, the location of Schönefeld/BBI Airport is remote compared to both city airports. ${ }^{21}$

\section{Conclusion}

This paper contributes to the assessment of external effects of airports by providing evidence for airports located in continental Europe where little evidence had been available. Focussing on two downtown airports, Tempelhof and Tegel, located in the same city, Berlin, but amid neighbourhoods characterized by distinctly different building structures, a negative impact was only found for the densely developed and populated areas within the Tempelhof air corridor where

${ }^{21}$ The results for accessebility indicators for Tempelhof, Tegel and Schönefeld Airports are $121,497,35,314$ and 15,491 for population potentiality and 52,293, 14,458 and 1775 for employment potentiality, respectively. 
land values are depreciated up to $9 \%$, which is in line with the findings of COLLINS \& EVANS (1994). Although there is evidence in the empirical literature for property prices within low density residential areas reacting less sensitively to aircraft noise (UYENO, HAMILTON, \& BIGGS, 1993), the complete absence of negative impact of Tegel Airport on land values is somewhat unique.

Since 2003 Berlin has been experiencing a boom in air traffic largely driven by low-cost carriers with yearly growth rates in passenger numbers of $8-15 \%$. With a growth rate of $8.5 \%$ from January to March 2007, passenger numbers are expected to exceed 20 million by the end of the year. Considering the recent boom in air traffic, it is likely that BBI immediately after inauguration will be undersized as the initial capacity will be limited to 22 million passengers. With regard to newly emerging discussion on the subject, our results suggest that taking social costs and benefits into account, suspension of the planned closure of Tegel airport might be justifiable. 


\section{Appendix: Data Collection}

We collected data on standard land values, FSI values and land use as determined by zoning regulations from atlases of standard land valuation (Bodenrichtwertatlanten) (SENATSVERWALTUNG FÜR STADTENTWICKLUNG BERLIN, 2006a). The Committee of Valuation Experts in Berlin has published this data at intervals of one to four years, since 1967.

Data collection was conducted by assigning values represented in atlases of standard land valuation to the official block structure as defined in December 2005. If more than one value was provided by an atlas of standard land valuation for one particular block, the average of the highest and lowest values was used. Price data has been collected individually for blocks, not used for purely residential purposes. In contrast, for pure residential areas, data on land values at a lower level of disaggregation ("Statistische Gebiete") was used, since variation was typically much smaller. Since Berlin consists of 195 statistical areas ("Statistische Gebiete"), this ensured that price data for residential areas was sufficiently disaggregated to draw a comprehensive picture. Aggregation to statistical area level was by averaging the highest and lowest standard land values within the respective area. To guarantee that averages represented a feasible proxy of overall area valuation, a threshold for the ratio of maximum-to-minimum land value within a statistical area was introduced. If this ratio was $>2$, then the extreme values were entered individually and averages were taken for the remaining blocks until the ratio fell below the threshold value. This had to be done in only very few cases, since generally maximum and minimum values were close. 
Tab. A1 Description of Variables and Abbreviations

\begin{tabular}{|c|c|}
\hline Variable & Description \\
\hline & In Hedonic Regression \\
\hline Business & $\begin{array}{l}\text { Dummy variable: } 1 \text { for blocks where a considerable amount of retail } \\
\text { and/or business activity takes place }\end{array}$ \\
\hline Industry & $\begin{array}{l}\text { Dummy variable: } 1 \text { for blocks where land is at least partially used for } \\
\text { industrial purposes }\end{array}$ \\
\hline West & $\begin{array}{l}\text { Dummy variable: } 1 \text { for blocks lying within the area of former West } \\
\text { Berlin }\end{array}$ \\
\hline FSI & Floor space index: Quotient of full-storey area and plot area \\
\hline $\mathrm{FSI}^{2}$ & Floor space index squared \\
\hline Dist Cent & Shortest great circle distance to CBD East or West in meters \\
\hline Dist_Metro & Great circle distance to next metro station in meters \\
\hline Dist Suburban & Great circle distance to next suburban railway station in meters \\
\hline Dist Water & Great circle distance to next water space (lake or river) in meters \\
\hline Dist_Schools & Great circle distance to next school in meters \\
\hline Dist_Play & Great circle distance to next playground in meters \\
\hline Dist Rail & Great circle distance to overground railway tracks in meters \\
\hline Pop_Prop_Sub6 & Proportion of population below the age of 6 \\
\hline Pop_Prop_6_15 & Proportion of population of age group of 6 to 15 years \\
\hline Pop Prop $1 \overline{5} 18$ & Proportion of population of age group of 15 to 18 years \\
\hline Pop_Prop_18_27 & Proportion of population of age group of 18 to 27 years \\
\hline Pop_Prop_65plus & Proportion of population above the age of 65 \\
\hline Pop_Density & Population density (inhabitants per square meter) \\
\hline Prop_Foreigners & Proportion of foreign population \\
\hline Prop Male & Proportion of male population \\
\hline Spatial_Lag & Spatial autoregressive term as described in the methodology section \\
\hline STRUCT & Vector of structural characteristics including FSI and $\mathrm{FSI}^{2}$ \\
\hline LOC & $\begin{array}{l}\text { Vector of location characteristics including Dist_Cent, Dist_Metro, } \\
\text { Dist_Suburban, Dist_Water, Dist_Schools, Dist_Play and Dist_Rail } \\
\text { Vector of neighbourhood characteristics including Pop Prop_Sub6, }\end{array}$ \\
\hline $\mathrm{NEIGH}$ & $\begin{array}{l}\text { Pop_Prop_6_15, Pop_Prop_15_18, Pop_Prop_18_27, } \\
\text { Pop_Prop_65plus, Pop_Density, Prop_Foreigners and Prop_Male }\end{array}$ \\
\hline
\end{tabular}


Tab. A2 Baseline Empirical Results of Hedonic Analysis (1-3)

\begin{tabular}{|c|c|c|c|}
\hline Variable & $\begin{array}{c}\text { (1) } \\
\text { Land Value (Log) }\end{array}$ & $\begin{array}{c}\text { (2) } \\
\text { Land Value (Log) }\end{array}$ & $\begin{array}{c}\text { (3) } \\
\text { Land Value (Log) }\end{array}$ \\
\hline Intercept & $\begin{array}{c}1.419380^{* * *} \\
(0.067685)\end{array}$ & $\begin{array}{c}1.409932^{* * *} \\
(0.069337)\end{array}$ & $\begin{array}{c}4.770188^{* * *} \\
(0.013161)\end{array}$ \\
\hline Business & $\begin{array}{c}-0.476554^{* * *} \\
(0.178338)\end{array}$ & $\begin{array}{c}-0.555828^{* * *} \\
(0.206850)\end{array}$ & $\begin{array}{c}0.049848 \\
(0.226227)\end{array}$ \\
\hline Industry & $\begin{array}{c}-0.201496^{* * *} \\
(0.052465)\end{array}$ & $\begin{array}{c}-0.659793^{* * *} \\
(0.184922)\end{array}$ & $\begin{array}{c}-0.483550^{* * * *} \\
(0.072417)\end{array}$ \\
\hline West & $\begin{array}{c}0.677466^{* * *} \\
(0.038296)\end{array}$ & $\begin{array}{c}0.678161^{* * *} \\
(0.041387)\end{array}$ & $\begin{array}{c}2.105208^{* * *} \\
(0.032986)\end{array}$ \\
\hline FSI & $\begin{array}{c}0.241159^{* * *} \\
(0.016054)\end{array}$ & $\begin{array}{c}0.250090^{* * *} \\
(0.015889)\end{array}$ & $\begin{array}{c}0.702962^{* * *} \\
(0.014560)\end{array}$ \\
\hline $\mathrm{FSI}^{2}$ & $\begin{array}{c}-0.025354^{* * *} \\
(0.005085)\end{array}$ & $\begin{array}{c}-0.030463^{* * *} \\
(0.004964)\end{array}$ & $\begin{array}{c}-0.056465^{* * *} \\
(0.005059)\end{array}$ \\
\hline Dist_Cent & $\begin{array}{c}-0.00000438^{* * *} \\
(0.000000587)\end{array}$ & $\begin{array}{c}-0.00000444^{* * *} \\
(0.000000599)\end{array}$ & $\begin{array}{c}-0.0000179^{* * *} \\
(0.00000084)\end{array}$ \\
\hline Dist_Metro & $\begin{array}{c}-0.00000211^{* * *} \\
(0.000000625)\end{array}$ & $\begin{array}{c}-0.000018^{* * *} \\
(0.000000659)\end{array}$ & $\begin{array}{c}-0.00000865^{* * *} \\
(0.00000118)\end{array}$ \\
\hline Dist_Suburban & $\begin{array}{c}-0.0000113^{* * *} \\
(0.00000341)\end{array}$ & $\begin{array}{c}-0.0000104^{* * *} \\
(0.00000362)\end{array}$ & $\begin{array}{l}-0.0000485^{* * *} \\
(0.00000392)\end{array}$ \\
\hline Dist_Water & $\begin{array}{c}-0.0000118^{* * *} \\
(0.00000201)\end{array}$ & $\begin{array}{c}-0.0000113^{* * *} \\
(0.000002)\end{array}$ & $\begin{array}{c}-0.0000415^{* * *} \\
(0.00000253)\end{array}$ \\
\hline Dist_Schools & & $\begin{array}{c}0.000000299 \\
(0.0000041)\end{array}$ & \\
\hline Dist_Play & & $\begin{array}{c}-0.0000019 \\
(0.00000302)\end{array}$ & \\
\hline Dist_Rail & $\begin{array}{l}0.0000122^{* * *} \\
(0.00000327)\end{array}$ & $\begin{array}{c}0.0000117^{* * *} \\
(0.0000034)\end{array}$ & $\begin{array}{c}0.0000468^{* * *} \\
(0.0000042)\end{array}$ \\
\hline Pop_Prop_Sub6 & $\begin{array}{l}0.062190^{* *} \\
(0.025417)\end{array}$ & $\begin{array}{l}0.054859^{* *} \\
(0.025282)\end{array}$ & $\begin{array}{l}0.103997^{* *} \\
(0.051869)\end{array}$ \\
\hline Pop_Prop_6_15 & & $\begin{array}{c}0.006943 \\
(0.019842)\end{array}$ & \\
\hline Pop_Prop_15_18 & & $\begin{array}{l}-0.006325 \\
(0.024015)\end{array}$ & \\
\hline Pop_Prop_18_27 & $\begin{array}{c}-0.046841^{* * *} \\
(0.0057)\end{array}$ & $\begin{array}{c}-0.040212^{* *} \\
(0.019973)\end{array}$ & $\begin{array}{c}-0.235991^{* * *} \\
(0.034376)\end{array}$ \\
\hline Pop_Prop_65plus & & $\begin{array}{c}-0.026906^{* *} \\
(0.013406)\end{array}$ & \\
\hline Pop_Density & $\begin{array}{c}-0.737185^{* * *} \\
(0.0012)\end{array}$ & $\begin{array}{c}-0.705164^{* * *} \\
(0.225787)\end{array}$ & $\begin{array}{c}-0.846712^{* * *} \\
(0.253823)\end{array}$ \\
\hline Prop_Foreigners & $\begin{array}{c}-0.085958^{* * *} \\
(0.018556)\end{array}$ & $\begin{array}{l}-0.059999^{*} \\
(0.035007)\end{array}$ & $\begin{array}{c}-0.096806^{* * *} \\
(0.030934)\end{array}$ \\
\hline Prop_Male & & $\begin{array}{c}0.006376 \\
(0.017495)\end{array}$ & \\
\hline Business $x \mathrm{FSI}$ & $\begin{array}{c}0.355788^{* * *} \\
(0.104214)\end{array}$ & $\begin{array}{c}0.371846^{* * *} \\
(0.110039)\end{array}$ & $\begin{array}{c}0.138966 \\
(0.129089)\end{array}$ \\
\hline Business $x \mathrm{FSI}^{2}$ & $\begin{array}{l}-0.030011^{*} \\
(0.015922)\end{array}$ & $\begin{array}{l}-0.027947^{*} \\
(0.016820)\end{array}$ & $\begin{array}{c}0.024650 \\
(0.019060)\end{array}$ \\
\hline Business x Dist_Cent & $\begin{array}{l}0.0000499^{* * *} \\
(0.00000637)\end{array}$ & $\begin{array}{l}0.0000534^{* * *} \\
(0.00000699)\end{array}$ & $\begin{array}{c}0.0000783^{* * *} \\
(0.0000114)\end{array}$ \\
\hline Business x Dist_Metro & $\begin{array}{l}-0.0000304^{*} \\
(0.0000161)\end{array}$ & $\begin{array}{c}-0.0000435^{* *} \\
(0.0000167)\end{array}$ & $\begin{array}{c}-0.000119^{* * *} \\
(0.0000187)\end{array}$ \\
\hline
\end{tabular}


Tab. A2 Baseline Empirical Results of Hedonic Analysis (2-3)

\begin{tabular}{|c|c|c|c|}
\hline Business x Dist_Suburban & $\begin{array}{c}-0.000064^{*} \\
(0.0000347)\end{array}$ & $\begin{array}{c}-0.0000927^{*} \\
(0.0000532)\end{array}$ & $\begin{array}{c}-0.000188^{* * *} \\
(0.0000442)\end{array}$ \\
\hline Business $x$ Dist_Water & $\begin{array}{c}0.0000402^{* * *} \\
(0.0000127)\end{array}$ & $\begin{array}{c}0.0000430^{* * *} \\
(0.0000129)\end{array}$ & $\begin{array}{c}0.0000240 \\
(0.0000153)\end{array}$ \\
\hline Business $x$ Dist_Schools & & $\begin{array}{r}-0.00000580 \\
(0.0000806)\end{array}$ & \\
\hline Business $x$ Dist_Play & & $\begin{array}{c}-0.0000188 \\
(0.0000885)\end{array}$ & \\
\hline Business x Dist_Rail & & $\begin{array}{c}0.0000512 \\
(0.0000498)\end{array}$ & \\
\hline Business x Pop_Prop_Sub6 & & $\begin{array}{l}-0.235726 \\
(0.202178)\end{array}$ & \\
\hline Business x Pop_Prop_6_15 & $\begin{array}{c}-0.577296^{* *} \\
(0.273710)\end{array}$ & $\begin{array}{l}-0.476419 \\
(0.315174)\end{array}$ & $\begin{array}{c}-0.864808^{* * *} \\
(0.256952)\end{array}$ \\
\hline Business x Pop_Prop_15_18 & & $\begin{array}{l}-0.105855 \\
(0.353263)\end{array}$ & \\
\hline Business x Pop_Prop_18_27 & $\begin{array}{c}-0.288284^{* * *} \\
(0.102699)\end{array}$ & $\begin{array}{c}-0.228749^{* *} \\
(0.100348)\end{array}$ & $\begin{array}{c}-0.421970^{*} \\
(0.244511)\end{array}$ \\
\hline Business x Pop_Prop_65plus & & $\begin{array}{c}0.178150 \\
(0.139387)\end{array}$ & \\
\hline Business $x$ Pop_Density & $\begin{array}{c}-2.547692^{* * *} \\
(0.907527)\end{array}$ & $\begin{array}{c}-2.555855^{* * *} \\
(0.882346)\end{array}$ & $\begin{array}{l}-2.082144^{*} \\
(1.211372)\end{array}$ \\
\hline Business $x$ Prop_Foreigners & $\begin{array}{c}0.188215^{* * *} \\
(0.058839)\end{array}$ & $\begin{array}{c}0.182792^{* * *} \\
(0.068185)\end{array}$ & $\begin{array}{c}0.360568^{* * *} \\
(0.107345)\end{array}$ \\
\hline Business x Prop_Male & & $\begin{array}{c}-0.014353 \\
(0.089939)\end{array}$ & \\
\hline Industry x FSI & & $\begin{array}{c}0.103909 \\
(0.137109)\end{array}$ & \\
\hline Industry $\times \mathrm{FSI}^{2}$ & & $\begin{array}{c}0.018786 \\
(0.031367)\end{array}$ & \\
\hline Industry x Dist_Cent & & $\begin{array}{c}0.0000161^{* *} \\
(0.00000693)\end{array}$ & \\
\hline Industry x Dist_Metro & & $\begin{array}{c}0.0000401 \\
(0.0000285)\end{array}$ & \\
\hline Industry x Dist_Suburban & $\begin{array}{c}-0.0000862^{* *} \\
(0.0000339)\end{array}$ & $\begin{array}{l}-0.0000768^{*} \\
(0.0000456)\end{array}$ & $\begin{array}{l}-0.0000303 \\
(0.0000407)\end{array}$ \\
\hline Industry x Dist_Water & & $\begin{array}{r}-0.00000984 \\
(0.0000211)\end{array}$ & \\
\hline Industry x Dist_Schools & $\begin{array}{l}-0.000180^{*} \\
(0.000105)\end{array}$ & $\begin{array}{l}-0.000111 \\
(0.000107)\end{array}$ & $\begin{array}{l}0.0000422 \\
(0.000150)\end{array}$ \\
\hline Industry x Dist_Play & $\begin{array}{c}0.000354^{* * *} \\
(0.000117)\end{array}$ & $\begin{array}{c}0.000240^{*} \\
(0.000126)\end{array}$ & $\begin{array}{l}0.000281^{*} \\
(0.000167)\end{array}$ \\
\hline Industry x Dist_Rail & & $\begin{array}{c}0.0000387 \\
(0.0000645)\end{array}$ & \\
\hline Industry x Pop_Prop_Sub6 & $\begin{array}{l}0.780610^{* *} \\
(0.352927)\end{array}$ & $\begin{array}{c}0.530378 \\
(0.361221)\end{array}$ & $\begin{array}{c}0.204225 \\
(0.408747)\end{array}$ \\
\hline Industry x Pop_Prop_6_15 & & $\begin{array}{c}0.050427 \\
(0.390445)\end{array}$ & \\
\hline Industry x Pop_Prop_15_18 & & $\begin{array}{c}0.018953 \\
(0.200147)\end{array}$ & \\
\hline Industry x Pop_Prop_18_27 & $\begin{array}{l}0.344214^{* *} \\
(0.352927)\end{array}$ & $\begin{array}{l}0.312817^{* *} \\
(0.129166)\end{array}$ & $\begin{array}{c}0.469512^{* * *} \\
(0.160178)\end{array}$ \\
\hline Industry x Pop_Prop_65plus & & $\begin{array}{c}-0.098714 \\
(0.126594)\end{array}$ & \\
\hline
\end{tabular}


Tab. A2 Baseline Empirical Results of Hedonic Analysis (3-3)

\begin{tabular}{|c|c|c|c|}
\hline Industry x Pop_Density & & $\begin{array}{c}2.107667 \\
(2.572701)\end{array}$ & \\
\hline Industry x Prop_Foreigners & & $\begin{array}{c}-0.077971 \\
(0.078824)\end{array}$ & \\
\hline Industry x Prop_Male & & $\begin{array}{c}0.140772 \\
(0.089877)\end{array}$ & \\
\hline West x FSI & $\begin{array}{c}-0.268710^{* * *} \\
(0.020125)\end{array}$ & $\begin{array}{c}-0.263000^{* * *} \\
(0.020561)\end{array}$ & $\begin{array}{c}-0.851855^{* * *} \\
(0.023213)\end{array}$ \\
\hline West $\times \mathrm{FSI}^{2}$ & $\begin{array}{c}0.039513^{* * *} \\
(0.004624)\end{array}$ & $\begin{array}{c}0.038739^{* * *} \\
(0.004887)\end{array}$ & $\begin{array}{c}0.121320^{* * *} \\
(0.006546)\end{array}$ \\
\hline West $x$ Dist_Cent & $\begin{array}{l}-0.0000317^{* * *} \\
(-0.00000194)\end{array}$ & $\begin{array}{c}-0.0000319^{* * *} \\
(0.00000196)\end{array}$ & $\begin{array}{l}-0.000103^{* * *} \\
(0.00000193)\end{array}$ \\
\hline West x Dist_Metro & $\begin{array}{l}0.0000236^{* * *} \\
(0.00000186)\end{array}$ & $\begin{array}{l}0.0000236^{* * *} \\
(0.00000198)\end{array}$ & $\begin{array}{l}0.0000727^{* * *} \\
(0.00000309)\end{array}$ \\
\hline West $x$ Dist_Suburban & $\begin{array}{l}-0.00000769^{*} \\
(0.00000398)\end{array}$ & $\begin{array}{l}-0.00000815^{*} \\
(0.00000421)\end{array}$ & $\begin{array}{c}-0.0000322^{* * *} \\
(0.00000556)\end{array}$ \\
\hline West x Dist_Water & $\begin{array}{c}0.00000979^{* * *} \\
(0.00000236)\end{array}$ & $\begin{array}{c}0.00000963^{* * *} \\
(0.00000234)\end{array}$ & $\begin{array}{c}0.000038^{* * *} \\
(0.00000359)\end{array}$ \\
\hline West x Dist_Schools & & $\begin{array}{c}0.00000277 \\
(0.00000764) \\
0.0000497^{* * *} \\
(0.00000863)\end{array}$ & \\
\hline West x Dist_Rail & $\begin{array}{c}-0.0000302^{* * *} \\
(0.00000430)\end{array}$ & $\begin{array}{l}-0.0000307^{* * *} \\
(0.00000445)\end{array}$ & $\begin{array}{c}-0.0000842^{* * *} \\
(0.00000682)\end{array}$ \\
\hline West x Pop_Prop_Sub6 & & $\begin{array}{c}0.032696 \\
(0.052924)\end{array}$ & \\
\hline West x Pop_Prop_6_15 & & $\begin{array}{l}-0.028291 \\
(0.034885)\end{array}$ & \\
\hline West x Pop_Prop_15_18 & $\begin{array}{c}-0.156947^{* * *} \\
(0.040899)\end{array}$ & $\begin{array}{c}-0.145205^{* * *} \\
(0.048004)\end{array}$ & $\begin{array}{c}-0.432046^{* * *} \\
(0.093982)\end{array}$ \\
\hline West x Pop_Prop_18_27 & & $\begin{array}{c}-0.035878 \\
(0.041474)\end{array}$ & \\
\hline West x Pop_Prop_65plus & & $\begin{array}{c}0.020985 \\
(0.024180)\end{array}$ & \\
\hline West x Pop_Density & $\begin{array}{c}-0.595791^{* * *} \\
(0.297937)\end{array}$ & $\begin{array}{l}-0.549493^{*} \\
(0.302441)\end{array}$ & $\begin{array}{c}-3.295263^{* * *} \\
(0.404408)\end{array}$ \\
\hline West x Prop_Foreigners & & $\begin{array}{l}-0.032307 \\
(0.041970)\end{array}$ & \\
\hline West $x$ Prop_Male & $\begin{array}{c}-0.134591^{* * *} \\
(0.025066)\end{array}$ & $\begin{array}{c}-0.141145^{* * *} \\
(0.032014)\end{array}$ & $\begin{array}{c}-0.311987^{* * *} \\
(0.047581)\end{array}$ \\
\hline Spatial_Lag & Yes & Yes & \\
\hline Block Sāmple & Berlin & Berlin & Berlin \\
\hline Observations & 11184 & 11184 & 11184 \\
\hline $\mathrm{R}^{2}$ & 0.966127 & 0.966472 & 0.893846 \\
\hline Adjusted $\mathrm{R}^{2}$ & 0.966002 & 0.966255 & 0.893465 \\
\hline
\end{tabular}

Notes: Model (1) represents our baseline hedonic model, which we obtain after stepwise deletion of statistically insignificant variables of the full model specification (2). In (3) we repeat our baseline regression omitting the spatial lag-variable. The dependent variable is the natural logarithm of standard land values in all models. Independent variables are described in table 1 . Standard errors (in parenthesis) are heteroscedasticity robust. ${ }^{*}$ denotes significance at the $10 \%$ level; ${ }^{* *}$ denotes significance at the $5 \%$ level; ${ }^{* * *}$ denotes significance at the $1 \%$ level. 


\section{Literature}

AHLFELDT, G., \& MAENNIG, W. (2007). Impact of Sports Arenas on Land Values: Evidence from Berlin. International Association of Sports Economists Working Papers, 703.

ALONSO, W. (1964). Location Theory. Cambridge, Mass.: M.I.T. Press.

BELL, R. (2001). The Impact of Airport Noise on Residential Real Estate. Appraisal Journal, 69(3), 312-321.

BOWES, D. R., \& IHLANFELDT, K. R. (2001). Identifying the Impacts of Rail Transit Stations on Residential Property Values. Journal of Urban Economics, 50(1), 1-25.

CAN, A., \& MEGBOLUGBE, I. (1997). Spatial Dependence and House Price Index Construction. Journal of Real Estate Finance and Economics, 14(2), 203-222.

CAROLL, T. M., CLAURETIE, T. M., \& JENSEN, J. (1996). Living Next to Godliness: Residential Property Values and Churches. Journal of Real Estate Finance and Economics, 12(3), 319-330.

CARRÉ, D. (2000). Berlin-Tempelhof, Liverpool-Speke, Paris-Le Bourget. années 30 architecture des aéroports; Airport Architecture of the Thirties; Flughafenarchitektur der dreißiger Jahre. Paris: Éditions du patrimoine.

CHESHIRE, P. C., \& SHEPPARD, S. (1995). On the Price of Land and the Value of Amenities. Economica, 62(246), 247-267.

COLLINS, A., \& EVANS, A. (1994). Aircraft Noise and Residential Property Values: An Artificial Neural Network Approach. Journal of Transport Economics and Policy, 28(2), 175197.

COLWELL, P. F., DEHRING, C. A., \& LASH, N. A. (2000). The Effect of Group Homes on Neighborhood Property Values. Land Economics, 76(4), 615-637.

COLWELL, P. F., \& MUNNEKE, H. J. (1997). The Structure of Urban Land Prices. Journal of Urban Economics, 41(3), 321-336.

COLWELL, P. F., \& MUNNEKE, H. J. (1999). Land Prices and Land Assembly in the Cbd. Journal of Real Estate Finance \& Economics, 18(2), 163-171.

COLWELL, P. F., \& SIRMANS, C. F. (1993). A Comment on Zoning, Returns to Scale, and the Value of Undeveloped Land. Review of Economics \& Statistics, 75(4), 783-786.

DEBREZION, G., PELS, E., \& RIETVELD, P. (2006). The Impact of Rail Transport on Real Estate Prices: An Empirical Analysis of the Dutch Housing Market. Tinbergen Institute Discussion Paper, 2006, 031 3(031 3).

DEMPS, L., \& PAESCHKE, C.-L. (1998). Flughafen Tempelhof. Die Geschichte einer Legende. Berlin: Ullstein.

DUBIN, R. A., \& SUNG, C.-H. (1990). Specification of Hedonic Regressions: Non-Nested Tests on Measures of Neighborhood Quality. Journal of Urban Economics, 27(1), 97110.

ELKINS, T. H., \& HOFMEISTER, B. (1988). Berlin: The Spatial Structure of a Divided City. London: Methuen. 
ELLEN, I. G., SCHILL, M. H., SUSIN, S., \& SCHWARTZ, A. E. (2001). Building Homes, Reviving Neighbourhoods: Spillovers from Subsidized Construction of Owner-Occupied Housing in New York City. Journal of Housing Research, 12(2), 185-216.

GALSTER, G., TATIAN, P., \& PETTIT, K. (2004). Supportive Housing and Neighborhood Property Value Externalities. Land Economics, 80(1), 33-54.

GALSTER, G., TATIAN, P., \& SMITH, R. (1999). The Impact of Neighbors Who Use Section 8 Certificates on Property Values. Housing Policy Debate, 10(4), 789-917.

GATZLAFF, D. H., \& SMITH, M. T. (1993). The Impact of the Miami Metrorail on the Value of Residences near Station Locations. Land Economics, 69(1), 54-66.

HALVORSEN, R., \& PALMOUIST, R. (1980). The Interpretation of Dummy Variables in Semilogarithmic Equations. American Economic Review, 70(3), 474-475.

HEIKKILA, E., GORDON, P., KIM, J. I., PEISER, R. B., RICHARDSON, H. W., \& DALE-JOHNSON, D. (1989). What Happened to the Cbd-Distance Gradient?: Land Values in a Policentric City. Environment and Planning, 21(2), 221-232.

ISAKSON, H. R. (1997). An Empirical Analysis of the Determinants of the Value of Vacant Land. Journal of Real Estate Research, 13(2), 103-114.

JORDAAN, A. C., DROST, B. E., \& MAKGATA, M. A. (2004). Land Value as a Function of Distance from the $\mathrm{Cbd}$ : The Case of the Eastern Suburbs of Pretoria. South African Journal of Economic and Management Sciences, 7(3), 532-541.

MEUSER, P. (2000). Vom Fliegerfeld zum Wiesenmeer. Geschichte und Zukunft Des Flughafens Tempelhof. Berlin: Quintessenz.

MIESZKOWSKI, P., \& SAPER, A. M. (1978). An Estimate of the Effects of Airport Noise on Property Values. Journal of Urban Economics, 5(4), 425-440.

MILLS, E. S., \& SIMENAUER, R. (1996). New Hedonic Estimates of Regional Constant Quality House Prices. Journal of Urban Economics, 39(2), 209-215.

MITCHELL, D. M. (2000). School Quality and Housing Values. Journal of Economics, 26(1), 53-68.

MUELLBAUER, J. (1974). Household Production Theory, Quality, and The "Hedonic Technique". American Economic Review, 64(5), 977-994.

MUNNEKE, H. J., \& SLADE, B. A. (2001). A Metropolitan Transaction-Based Commercial Price Index: A Time-Varying Parameter Approach. Real Estate Economics, 29(1), 55-85.

NELSON, J. P. (1979). Airport Noise, Location Rent, and the Market for Residential Amenities. Journal of Environmental Economics and Management, 6(4), 320-331.

NELSON, J. P. (1980). Airports and Property Values: A Survey of Recent Evidence. Journal of Transport Economics and Policy, 14(1), 37-52.

PENNINGTON, G., TOPHAM, N., \& WARD, R. (1990). Aircraft Noise and Residential Property Values Adjacent to Manchester International Airport. Journal of Transport Economics and Policy, 24(1), 49-59.

REDDING, S. J., STURM, D. M., \& WOLF, N. (2007). History and Industry Location: Evidence from German Airports. Centre for Economic Policy Discussion Paper Series, 2007; 6345: International Trade. 
ROSEN, S. (1974). Hedonic Prices and Implicit Markets : Product Differentiation in Pure Competition. Journal of Political Economy, 82(1), 34-55.

SCHMITZ, F. (1997). Flughafen Tempelhof. Berlins Tor Zur Welt. Berlin: be.bra.

SENATSVERWALTUNG FÜR STADTENTWICKLUNG BERLIN (2006a). Bodenrichtwertatlas 2006. Berlin.

SENATSVERWALTUNG FÜR STADTENTWICKLUNG BERLIN (2006b). Urban and Environmental Information System. Berlin.

SENATSVERWALTUNG FÜR WIRTSCHAFT ARBEIT UND FRAUEN (2004). Zentrenatlas Wirtschaftsstandort Berlin (2. ed.). Berlin: Regioverlag.

STEINKE, S. (2006). Haupstadtairport Berlin-Tegel. Sechseck am Limit. Flug Revue, 2006(6), 68-71.

THÜNEN, J. H. V. (1826). Der isolierte Staat in Beziehung auf Landwirtschaft und Nationalökonomie, oder Untersuchungen über den Einfluss, den die Getreidepreise, der Reichtum des Bodens und die Abgaben auf Ackerbau Ausüben. Hamburg: Perthes.

TOMKINS, J., TOPHAM, N., TWOMEY, J., \& WARD, R. (1998). Noise Versus Access: The Impact of an Airport in an Urban Property Market. Urban Studies, 35(2), 243-258.

TU, C. C. (2005). How Does a New Sports Stadium Affect Housing Values? The Case of Fedex Field. Land Economics, 81(3), 379-395.

UYENO, D., HAMILTON, S. W., \& BIGGS, A. J. G. (1993). Density of Residential Land Use and the Impact of Airport Noise. Journal of Transport Economics and Policy, 27(1), 3-18.

VAN PRAAG, B. M. S., \& BAARSMA, B. E. (2005). Using Happiness Surveys to Value Intangibles: The Case of Airport Noise. Economic Journal, 115(500), 224-246.

WU, F. (2000). Modelling Intrametropolitan Location of Foreign Investment Firms in a Chinese City. Urban Studies, 37(13), 2441-2464. 


\section{Hamburg Contemporary Economic Discussions}

(Download: http://www.uni-hamburg.de/economicpolicy/discussions.html)

01/2005 FEDDERSEN, A. / MAENNIG, W.: Trends in Competitive Balance: Is there Evidence for Growing Imbalance in Professional Sport Leagues?, January 2005.

02/2005 SIEVERS, T.: Information-driven Clustering - An Alternative to the Knowledge Spillover Story, February 2005.

03/2005 SIEVERS, T.: A Vector-based Approach to Modeling Knowledge in Economics, February 2005.

04/2005 BUETTNER, N. / MAENNIG, W. / MENSSEN, M.: Zur Ableitung einfacher Multiplikatoren für die Planung von Infrastrukturkosten anhand der Aufwendungen für Sportstätten - eine Untersuchung anhand der Fußball-WM 2006, May 2005.

01/2006 FEDDERSEN, A.: Economic Consequences of the UEFA Champions League for National Championships - The Case of Germany, May 2006.

02/2006 FEDDERSEN, A.: Measuring Between-season Competitive Balance with Markov Chains, July 2006.

03/2006 FEDDERSEN, A. / VOEPEL, H.: Staatliche Hilfen für Profifußballclubs in finanziellen Notlagen? - Die Kommunen im Konflikt zwischen Imageeffekten und Moral-Hazard-Problemen, September 2006.

04/2006 MAENNIG, W. / SCHWARTHOFF, F.: Stadium Architecture and Regional Economic Development: International Experience and the Plans of Durban, October 2006. 


\section{Hamburg Contemporary Economic Discussions}

(Download: http://www.uni-hamburg.de/economicpolicy/discussions.html)

01

$\mathrm{O} 2$

03

04

05

06

07

08

O9

10

11

AHLFELDT, G. I MAENNIG, W.: The Role of Architecture on Urban Revitalization: The Case of "Olympic Arenas" in Berlin-Prenzlauer Berg, 2007.

FEDDERSEN, A. / MAENNIG, W. / ZIMMERMANN, P.: How to Win the Olympic Games - The Empirics of Key Success Factors of Olympic Bids, 2007.

AHLFELDT, G. / MAENNIG, W.: The Impact of Sports Arenas on Locational Attractivity: Evidence from Berlin, 2007.

DU PLESSIS, S. I MAENNIG, W.: World Cup 2010: South African Economic Perspectives and Policy Challenges Informed by the Experience of Germany 2006, 2007.

HEYNE, M. / MAENNIG, W. / SUESSMUTH, B.: Mega-sporting Events as Experience Goods, 2007.

DUST, L. / MAENNIG, W.: Shrinking and Growing Metropolitan Areas - Asymmetric Real Estate Price Reactions? The Case of German Single-family Houses, 2007.

JASMAND, S. / MAENNIG, W.: Regional Income and Employment Effects of the 1972 Munich Olympic Summer Games, 2007.

HAGN, F. / MAENNIG W.: Labour Market Effects of the 2006 Soccer World Cup in Germany, 2007.

HAGN, F. / MAENNIG, W.: Employment Effects of the World Cup 1974 in Germany.

MAENNIG, W.: One Year Later: A Re-appraisal of the Economics of the 2006 Soccer World Cup, 2007.

AHLFELDT, G., MAENNIG, W.: Assessing External Effects of City Airports: Land Values in Berlin, 2007. 
